\title{
Bridged Heterocyclium Di- Cationic closo-Icosahedral Perfluoroborane, Borane, and Carborane Salts via Aqueous, Open-Air Benchtop Synthesis
}

Scott A. Shackelford, ${ }^{*}$ John L. Belletire ${ }^{\dagger}{ }^{J}$ Jerry A. Boatz, Stefan Schneider, Amanda K. Wheaton, ${ }^{\dagger}$ Brett A. Wight, ${ }^{\dagger}$ Herman L. Ammon, ${ }^{*}$ Dmitry V. Peryshkov, ${ }^{\S}$ and Steven H. Strauss ${ }^{\S}$

Air Force Research Laboratory, Propellants Branch (AFRL/RZSP), 10 East Saturn Blvd., Edwards AFB, CA 93524-7680, Department of Chemistry and Biochemistry, University of Maryland, College Park, MD 20742, and Department of Chemistry,

Colorado State University, Fort Collins, CO 80523

scottshack@roadrunner.com

$\dagger$ ERC, Inc. at AFRL/RZSP, Edwards AFB, CA 93524.

$\ddagger$ Department of Chemistry and Biochemistry, University of Maryland, College Park, MD 20742.

$\S$ Department of Chemistry, Colorado State University, Ft. Collins, CO 80523.

\section{SUPPLEMENTAL INFORMATION}

$\underline{\text { Description }}$

$\underline{\text { Table of Contents }}$

\section{$\underline{\text { Description }}$}

References/Notes

General Experimental Comments 
FTIR Analyses $\quad 4$

High Resolution Mass Spectrometry (HRMS) Analyses 4

Single Crystal X-ray Analyses 4

Melting Point Determination 4

Ion Chromatography Halide Analyses 4

General Conventional Alkylation Procedure for the Intermediate Bridged Heterocyclium Di-Cation Di-Halide Salt Reactants (1-5). 5

Detailed Synthesis Parameters and Spectroscopic Data for Salts (1-5):

[1,4-di-(4-amino-1,2,4,-triazolium-1N)-2-butyne][Br $]_{2}$ (1) 5

[trans-1,4-di-(4-amino-1,2,4,-triazolium-1N)-2-butene][Br $]_{2}$ (2) 5

[trans-1,4-di-(1-amino-1,2,3-triazolium-3N)-2-butene $][\mathrm{Br}]_{2}$ (3) 6

[cis-1,4-di-(4-amino-1,2,4,-triazolium-1N)-2-butene $][\mathrm{Cl}]_{2}$ (4) 6

[trans-1,4-di-(1-methylimidazoium-3N)-2-butene][Br $]_{2}$ (5) 6

Larger-Scale General Metathesis Reaction Procedure for Bridged Heterocyclium DiCation closo-Perfluoroborane, closo-Borane, and closo-Carborane Salt Products (6-15 and 18).

Detailed Synthesis Parameters and Spectroscopic Data for Salts (6-16 and 18):

[1,4-di-(4-amino-1,2,4-triazolium-1N)-2-butyne][closo- $\left.\mathrm{B}_{12} \mathrm{H}_{12}\right]$ (6) 8

[1,4-di-(4-amino-1,2,4-triazolium-1N)-2-butyne][closo- $\left.\mathrm{CB}_{11} \mathrm{H}_{12}\right]$ (7) 8

[trans-1,4-di-(4-amino-1,2,4,-triazolium-1N)-2-butene][closo- $\left.\mathrm{B}_{12} \mathrm{H}_{12}\right] \mathbf{( 8 )} \quad 8$

[trans-1,4-di-(4-amino-1,2,4,-triazolium-1N)-2-butene][closo- $\left.\mathrm{CB}_{11} \mathrm{H}_{12}\right]$ (9) 8

[trans-1,4-di-(1-amino-1,2,3,-triazolium-3N)-2-butene][closo- $\left.\mathrm{B}_{12} \mathrm{H}_{12}\right]$ (10) 9

[trans-1,4-di-(1-amino-1,2,3,-triazolium-3N)-2-butene][closo- $\left.\mathrm{CB}_{11} \mathrm{H}_{12}\right]$ (11) 9

[cis-1,4-di-(4-amino-1,2,4,-triazolium-1N)-2-butene][closo- $\left.\mathrm{B}_{12} \mathrm{H}_{12}\right]$ (12) 9

[cis-1,4-di-(4-amino-1,2,4,-triazolium-1N)-2-butene][closo- $\left.\mathrm{CB}_{11} \mathrm{H}_{12}\right]$ (13) 9

[trans-1,4-di-(1-methylimidazolium-3N)-2-butene][closo- $\left.\mathrm{B}_{12} \mathrm{H}_{12}\right]$ (14) 10

[trans-1,4-di-(1-methylimidazolium-3N)-2-butene][closo- $\left.\mathrm{CB}_{11} \mathrm{H}_{12}\right]$ (15) 10 
[trans-1,4-di-(4-amino-1,2,4-triazolium-1N)-2-butene][closo- $\left.\mathrm{B}_{12} \mathrm{~F}_{12}\right]$ (16)

Smaller-Scale General Metathesis Reaction Procedure and X-ray Data for Bridged Heterocyclium Di-Cation closo-Perfluoroborane Salt Products (16-18).

Detailed X-ray Data, Synthesis Parameters, and Spectroscopic Data for Salts (16-18):

[trans-1,4-di-(4-amino-1,2,4-triazolium-1N)-2-butene $]\left[\right.$ closo- $\left.\mathrm{B}_{12} \mathrm{~F}_{12}\right]$ (16) 11

[trans-1,4-di-(1-amino-1,2,3-triazolium-3N)-2-butene][closo- $\left.\mathrm{B}_{12} \mathrm{~F}_{12}\right]$ (17) 14

[1,4-di-(4-amino-1,2,4-triazolium-1N)-2-butyne][closo- $\left.\mathrm{B}_{12} \mathrm{~F}_{12}\right]$ (18) 16

$\begin{array}{ll}\text { Melting Point Detailed Data } & 18\end{array}$

Ion Chromatography $\mathrm{Cl}^{-}$or $\mathrm{Br}^{-}$Analyses Data 23

\section{References/Notes.}

References (1) - (20) appear in the main paper.

(21) See under X-ray Analyses section below on this page.

(22) Handbook of Chemistry and Physics, $49^{\text {th }}$ ed.; Weast, R. C., Ed.; CRC: Cleveland, OH, 1968. See under Ion Chromatography Results section below (page 23).

\section{General Experimental Comments.}

Caution! While no special protective equipment or handling were used with salts 6-18, be aware that these are high energy materials and can be initiated to rapid energy releasing phenomena. Thermal initiation can occur on a hot plate surface (c.a. $>200{ }^{\circ} \mathrm{C}$ ) to rapid combustion with salt $\mathbf{6}$ while salt $\mathbf{8}$ only undergoes a slow thermochemical decomposition. ${ }^{2}$ Recent standard impact, friction, and electrostatic discharge (ESD) hazards testing were conducted on salts 6-8, 10, 12, and 18. All five salts displayed spark sensitivity at 0.09 Joules (ESD test). Impact test results were determined at the $100 \%$ non-initiation level, and salt 12 proved most sensitive to impact at $54 \mathrm{Kg}$-cm while salt 18 was the least sensitive at $147 \mathrm{Kg}-\mathrm{cm}$. These two 100\% "No-Go" values compare with known explosives for which the following more sensitive 50\% initiation $\mathrm{Kg}$-cm values are available: CL-20 at 33; PETN at 67; HMX at 115; and, RDX at 117. Salt 12 was the most sensitive to friction at $16.0 \mathrm{Kg}$ $\mathrm{cm}$, while salts $\mathbf{7 , 1 0}$, and $\mathbf{1 8}$ gave no initiation at the maximum $21.6 \mathrm{Kg}$-cm machine friction threshold.

All neutral heterocycles used to synthesize the bridged heterocyclium salts 1-18 were purchased commercially with one exception. The 1-amino-1,2,3-triazole compound was 
synthesized according to the procedure cited. ${ }^{18}$ De-ionized (DI) water was obtained from an in-house Millipore MILL-Q Reagent Grade Water System at an 18 megaohm cm purity level. All organic solvents were commercially purchased as either Reagent Grade or HPLC purity, and were used as received.

NMR Analyses. A Bruker Avance 400 Digital NMR instrument was used to obtain both proton $\left({ }^{1} \mathrm{H}\right)$ and ${ }^{13} \mathrm{C}$ spectra.

FTIR Analyses. Fourier transform infrared spectra (FTIR) were taken as powder samples using a Nicolet 6700 Spectrometer in air using with an HATR optical system. Reported are the significant peaks observed. An FTIR spectrum of the $\mathrm{K}_{2}\left[\mathrm{~B}_{12} \mathrm{~F}_{12}\right]$ reactant salt reveals only two very strong peaks at $1221 \mathrm{~cm}^{-1}$ and $719 \mathrm{~cm}^{-1}$. Therefore, the presence of the $\left[\mathrm{B}_{12} \mathrm{~F}_{12}\right]^{2-}$ di-anion is revealed in three product salts 16-18 by two very strong peaks in the $1220 \mathrm{~cm}^{-1}$ and $720 \mathrm{~cm}^{-1}$ regions. The $\left[\mathrm{B}_{12} \mathrm{~F}_{12}\right]^{2-}$ di-anion symbol was also placed behind the appropriate FTIR peaks $\left(\mathrm{cm}^{-1}\right)$ to identify these two characteristic peaks for each product salt 16 (pages 10 and 11), 17 (page 14), and 18 (pages 10 and 16).

High Resolution Mass Spectometry Analyses. High resolution mass specta (HRMS) analyses were conducted at UCR Mass Spectrometry Facility, Department of Chemistry, University of California, 501 Big Springs Road (CS1), Riverside, CA 92521, Dr. Richard W. Kondrat, Academic Coordinator, and Mr. Ronald B. New, Staff Research Associate. Analyses were conducted in either the $+e v$ or $-e v$ mode. In all five borane product salts (2, $4,6,8)$ and two perfluoroborane salts $(17,18)$, the $\mathrm{Na}$ atom appeared in the resolved salt specta. According to UCR Mass Spectrometry Facility personnel, $\mathrm{Na}$ is endemic to the environment, is easily ionized; and therefore, often appears in HRMS results, and the Na seen in several salt products could have come from solvents stored in glass. All seven salts were verified by these HRMS analyses.

Single Crystal X-ray Analyses. The single-crystal X-ray diffraction data were collected on a Bruker 3-circle-platform diffractometer equipped with a SMART APEX 2 detector with the $\chi$-axis fixed at $54.74^{\circ}$ and using $\mathrm{MoK}_{\alpha}$ or $\mathrm{CuK}_{\alpha}$ radiation from a fine-focus tube. The goniometer head, equipped with a nylon Cryoloop and magnetic base, was used to mount the crystals using perfluoropolyether oil. The data collection as well as structure solution and refinement were carried out using standard procedures with the APEX2 V.2.14, SMART V.5.622, SAINT 7.24A, SADABS, and SHELXTL software packages and programs. $^{21}$ Crystal data and refinement details of crystals of 16-18 are given in Table 1-3. Crystallographic data are also available in CIF-format.

(21) APEX2 V.2.1-4, SMART V.5.622, SAINT 7.24A, SADABS, SHELXTL ed.; BrukerAXS, INC.: Madison, WI USA, 2007.

Melting Point Determination. Visually-determined melting point values come from a Stanford Research Systems OptiMelt MPA100-Automated Melting Point Apparatus equipped with digital image video playback software. Observed melting point behavior tends to differ somewhat from what is seen with neutral covalent organic compounds; so, more detail is provided in Table 4 at the end of this section. 
Ion Chromatography $\mathrm{Cl}^{-}$or $\mathrm{Br}^{-}$Analysis Results. Ionic $\mathrm{Cl}^{-}$or $\mathrm{Br}^{-}$concentrations were determined for product salts (6-18), obtained from intermediate di-bromide and dichloride salts (1-5), by Ion Chromatography using a Waters HPLC equipped with a Waters 432 conductivity detector and a Phenomenex STAR-ION A300 100 x 4.6 mm ID (PEEK) analytical column. A Borate/Gluconate eluent was used and system conditions were set according to Waters method \#980895.

\section{General Conventional Alkylation Procedure for the Intermediate Bridged Heterocyclium Di-Cation Di-Halide Salt Reactants (1-5).}

Either the 1,4-di-halo-2-butene or 1,4-di-halo-2-butyne reagent and the selected neutral triazole or 1-methylimiazole heterocycle were dissolved in Reagent Grade $\mathrm{CH}_{3} \mathrm{CN}$ solvent and stirred under reflux using a Teflon ${ }^{\circledR}$-coated magnetic stirring bar until the precipitated salt product was obtained. Cooling the reaction suspension, vacuum filtration, rinsing the resultant filter cake with several $\mathrm{mL}$ of $\mathrm{CH}_{3} \mathrm{CN}$ or $\mathrm{Et}_{2} \mathrm{O}$, and drying gave one of the selected bridged heterocyclium di-cation di-halide salts 1-4. Slight exceptions to the above procedure are noted in the individual salt product descriptions below. In these alkylations, the millimoles recorded reflect the stated purity of the specific reagent used. The heterocyclium di-cation di-bromide salt 5 was synthesized using a microwave-assisted synthesis procedure.

[1,4-di-(4-amino-1,2,4,-triazolium-1N)-2-butyne][Br $]_{2}$ (1): A $100 \mathrm{~mL} \mathrm{24/40} \mathrm{jointed}$ single-necked recovery flask was charged with $2.013 \mathrm{~g}(9.027 \mathrm{mmol})$ of $95 \%$ pure $1,4-$ dibromo-2-butyne, $10 \mathrm{~mL} \mathrm{CH} 3 \mathrm{CN}, 1.502 \mathrm{~g}$ (17.685 mmol) of 99\% 4-amino-1,2,4-triazole, and $30 \mathrm{~mL}$ additional $\mathrm{CH}_{3} \mathrm{CN}$. Refluxing $22 \mathrm{~h}$, cooling for $95 \mathrm{~min}$ in the refrigerator, filtration, rinsing with $5 \mathrm{~mL}$ pre-chilled $\left(+3.0^{\circ} \mathrm{C}\right)$ in several portions, and drying under high vacuum for $22 \mathrm{~h}$ at $\mathrm{rt}$ afforded $3.261 \mathrm{~g}$ of light tan salt 1 (97\% yield): ${ }^{1} \mathrm{H} \mathrm{NMR} 400 \mathrm{MHz}$, std. DMSO-d 6 ( $\delta 2.50) ; \delta 10.33(\mathrm{~s}, 2 \mathrm{H}), 9.29(\mathrm{~s}, 2 \mathrm{H}),\left(7.08(\mathrm{brs}, 4 \mathrm{H}), 5.53(\mathrm{~s}, 4 \mathrm{H}) ;{ }^{13} \mathrm{C} \mathrm{NMR}\right.$ $(100 \mathrm{MHz}$, std. DMSO-d 6 ( $\delta 39.51) ; \delta 145.63,142.94,78.88,41.89 ;$ FTIR (HATR) $\mathrm{cm}^{-1}$, 3255, 3116, 3086, 2986, 2948, 2903, 1618, 1562, 1516, 1417, 1359, 1204, 1155, 1070, 995, 884, 771, 645, 609; HRMS calcd for $\left[\text { Cation }^{2+}+\mathrm{Br}^{-}\right]^{+} 299.0363$, found 299.0367.

[trans-1,4-di-(4-amino-1,2,4,-triazolium-1N)-2-butene][Br] ${ }_{\mathbf{2}}$ (2): A $100 \mathrm{~mL} \mathrm{24/40}$ jointed single-necked recovery flask was charged with $1.506 \mathrm{~g}(6.831 \mathrm{mmol})$ of $97 \%$ pure trans-1,4-dibromo-2-butene, $1.160 \mathrm{~g}(13.658 \mathrm{mmol})$ of $99 \%$ 4-amino-1,2,4-triazole, and 40 $\mathrm{mL} \mathrm{CH}{ }_{3} \mathrm{CN}$. Refluxing $6.5 \mathrm{~h}$, cooling to rt overnight, filtration, rinsing with $3 \times 5 \mathrm{~mL}$ $\mathrm{CH}_{3} \mathrm{CN}$, and drying under high vacuum $(40-50 \mathrm{mTorr})$ at $60^{\circ} \mathrm{C}$ for $50 \mathrm{~h}, 20 \mathrm{~min}$ afforded $2.560 \mathrm{~g}$ of white salt 2 (98\% yield): ${ }^{1} \mathrm{H}$ NMR $400 \mathrm{MHz}$, std. DMSO-d $\mathrm{d}_{6}(\delta 2.50) ; \delta 10.25$ (s, 2H), 9.24 (s, 2H), 7.05 (brs, 4H), 6.08-6.06 ( m, 2H), 5.10-5.08 (m, 4H); ${ }^{13} \mathrm{C} \mathrm{NMR} \mathrm{(100}$ MHz, std. DMSO-d 6 ( 39.51$) ; \delta 145.38,142.82,128.29,52.44$; FTIR (HATR) cm ${ }^{-1}, 3254$, 3142 , 3096, 3041, 2997, 1614, 1583, 1558, 1514, 1439, 1406, 1352, 1326, 1269, 1226, 1207, 1174, 1150, 1071, 1023, 994, 940, 909, 858, 769, 732, 682, 647, 617; HRMS calcd for $\left[\text { Cation }^{2+}+\mathrm{Br}^{-}\right]^{+}$301.0519, found 301.0521. 
[trans-1,4-di-(1-amino-1,2,3-triazolium-3N)-2-butene $][\mathrm{Br}]_{2}$ (3): Six Biotage (nee Personal Microwave) Initiator Emrys ${ }^{\mathrm{TM}} 10-20 \mathrm{~mL}$ process vials containing a coated magnetic stir bar are each are charged with an average of $0.600 \mathrm{~g}(2.721 \mathrm{mmol}) 97 \%$ trans1,4-di-(1-amino-1,2,3,-triazolium)-2-butene di-bromide, an average of $0.472 \mathrm{~g}$ (5.614 mmol) 1-amino-1,2,3-triazole (1AT), ${ }^{18}$ with $20 \mathrm{~mL} \mathrm{CH}_{3} \mathrm{CN}$ solvent in each reaction vessel. Each reaction vessel was capped/sealed and automatically microwaved at $100{ }^{\circ} \mathrm{C}$ for 45 min successively using the reaction vessel transfer feature that is part of the software set-up. The white solid suspension is cooled to $\mathrm{rt}$ and is then placed into a freezer $\left(-13.5^{\circ} \mathrm{C}\right)$. The suspension of each vial is combined and vacuum filtered; then, each reaction vessel is successively rinsed with $2 \mathrm{~mL}$ pre-chilled $\left(-13.5^{\circ} \mathrm{C}\right) \mathrm{CH}_{3} \mathrm{CN}$ which is filtered through the combined solid cake. The solid cake is then rinsed with $4 \mathrm{~mL}$ additional pre-chilled $\mathrm{CH}_{3} \mathrm{CN}$ in to portions. Finally, the white cake is rinsed with $5 \mathrm{~mL} \mathrm{Et}_{2} \mathrm{O}$ and is then dried at $50{ }^{\circ} \mathrm{C}$ for $3 \mathrm{~d}$ on the house vacuum to yield $1.398 \mathrm{~g}(22 \%)$ of slightly off-white solid salt 3 containing less than $1 \%$ unreacted (1AT): ${ }^{1} \mathrm{H}$ NMR $400 \mathrm{MHz}$, std. DMSO-d ${ }_{6}(\delta 2.50) ; \delta$ $8.87(\mathrm{~d}, 2 \mathrm{H}), 8.69$ (d, 2H), 8.43 (brs, 4H), 6.18-6.16 ( m, 2H), 5.31-5.30 (m, 4H); ${ }^{13} \mathrm{C} \mathrm{NMR}$ $(100 \mathrm{MHz}$, std. DMSO-d 6 ( $\delta 39.51) ; \delta 130.91,128.56,126.76,53.35$; FTIR (HATR) $\mathrm{cm}^{-1}$, 3171, 3131, 3112, 3083, 3041, 2972, 2961, 2842, 2800, 1622, 1534, 1476, 1426, 1364, 1330, 1234, 1187, 1160, 1079, 1055, 1025, 975, 962, 905, 810, 751, 697, 654, 628; HRMS calcd for $\left[\text { Cation }^{2+}+\mathrm{Br}^{-}\right]^{+} 301.0519$, found 301.0524 .

[cis-1,4-di-(4-amino-1,2,4,-triazolium-1N)-2-butene $][\mathbf{C l}]_{2}$ (4): A $50 \mathrm{~mL} \mathrm{24/40}$ jointed single-necked recovery flask was charged with $0.590 \mathrm{~g}(4.480 \mathrm{mmol})$ of $95 \%$ pure cis-1,4-dichloro-2-butene, $15 \mathrm{~mL} \mathrm{CH}_{3} \mathrm{CN}, 0.746 \mathrm{~g}$ (8.778 mmol) of 99\% 4-amino-1,2,4triazol (4AT), and another $5 \mathrm{~mL} \mathrm{CH}_{3} \mathrm{CN}$. Refluxing $95 \mathrm{~h}$, cooling to rt, and decanting left the dark brown solid stuck to the insides of the reaction flask. Next, $6 \mathrm{~mL}$ fresh $\mathrm{CH}_{3} \mathrm{CN}$ were added to the reaction flask. Refluxing 6 min, cooling to rt, and decanting the $\mathrm{CH}_{3} \mathrm{CN}$ ensued. This $\mathrm{CH}_{3} \mathrm{CN}$ reflux trituration was repeated with a 5 min reflux and decanting the solvent to leach out all but $5.6 \%$ of unreacted 4AT. Drying 6 days and $17 \mathrm{~h}$, or $161 \mathrm{~h}$, at $\mathrm{rt}$ under a high vacuum afforded $1.267 \mathrm{~g}$ of clear, hard dark brown salt 4 (98\% yield incl. 5.6 $\%$ 4AT): ${ }^{1} \mathrm{H}$ NMR $400 \mathrm{MHz}$, std. DMSO-d 6 ( $\left.\delta 2.50\right) ; \delta 10.46(\mathrm{~s}, 2 \mathrm{H}), 9.26(\mathrm{~s}, 2 \mathrm{H}), 8.86(\mathrm{~s}$, unreacted 4AT), 7.20 (brs, 4H), 6.05-6.03 ( m, 2H), 5.33-5.32 (m, 4H); ${ }^{13} \mathrm{C}$ NMR $(100 \mathrm{MHz}$, std. DMSO-d ${ }_{6}(\delta 39.51) ; \delta 145.24,143.95$ (unreacted 4AT), 142.64, 127.54, 48.42; FTIR (HATR) cm $\mathrm{cm}^{-1}, 3179$ (sh), 3089, 3015, 1630, 1560, 1409, 1324, 1156, 1070, 1001, 964, 809, 612; HRMS calcd for [Cation $\left.{ }^{2+}+\mathrm{Cl}^{-}\right]^{+} 257.1024$, found 257.1029 .

Note: Regarding assignment of the ${ }^{13} \mathrm{C}$ NMR peak at $\delta 143.95$ as being unreacted $4 \mathrm{AT}$, a smaller reaction scale gave a ${ }^{13} \mathrm{C}$ NMR with three peaks clustered at 145.24 (large), 143.95 (small), 142.64 (large). The 143.95 peak also was suspected to come from 18\% unreacted $4 \mathrm{AT}$ seen in the proton NMR spectra. Trituration in hot $\mathrm{CH}_{3} \mathrm{CN}$ removed most of the unreacted 4AT so that the triturated sample gave ${ }^{13} \mathrm{C}$ NMR peaks only at 145.25 and 142.66 further confirming that the smaller middle peak is unreacted 4AT.

[trans-1,4-di-(1-methylimidazoium-3N)-2-butene][Br $]_{\mathbf{2}}$ (5): A $100 \mathrm{~mL} \mathrm{24/40} \mathrm{jointed}$ single-necked recovery flask was charged with $1.500 \mathrm{~g}(6.803 \mathrm{mmol})$ of $97 \%$ pure trans-1,4dibromo-2-butene, $1.117 \mathrm{~g}$ (13.604 mmol) of 99\% 1-methylimidazole, and $15 \mathrm{~mL}$ additional $\mathrm{CH}_{3} \mathrm{CN}$. Refluxing $6 \mathrm{~h}$, cooling in the freezer $\left(-13.5^{\circ} \mathrm{C}\right)$ over the weekend, filtration, rinsing with $4 \times 10 \mathrm{~mL} \mathrm{Et}_{2} \mathrm{O}$, and drying $24 \mathrm{~h}$ at $60^{\circ} \mathrm{C}$ on the house vacuum 
afforded $2.442 \mathrm{~g}$ of white salt 5 (95\% yield): ${ }^{1} \mathrm{H}$ NMR $400 \mathrm{MHz}$, std. DMSO-d 6 ( $\left.\delta 2.50\right) ; \delta$ $9.24(\mathrm{~s}, 2 \mathrm{H}), 7.76(\mathrm{~d}, 4 \mathrm{H}), 6.01-5.99(\mathrm{~m}, 2 \mathrm{H}), 4.91-4,90(\mathrm{~m}, 4 \mathrm{H}), 3.88(\mathrm{~s}, 6 \mathrm{H}) ;{ }^{13} \mathrm{C} \mathrm{NMR}$ $(100 \mathrm{MHz}$, std. DMSO-d 6 ( $\delta 39.51) ; \delta 136.66,129.02,123.78,1.22 .34 ;$ 49.40, 35.87; FTIR (HATR) cm $\mathrm{cm}^{-1}, 3136,3074,3043,2938,1777,1675,1563,1475,1409,1387,1371,1335$, 1296, 1256, 1159, 1137, 1093, 1074, 984, 956, 890, 846, 792, 754, 652, 616; HRMS calcd for $\left[\text { Cation }^{2+}+\mathrm{Br}^{-}\right]^{+}$297.0709, found 297.0715.

\section{Larger-Scale General Metathesis Reaction Procedure for Bridged Heterocyclium Di- Cation closo-Perfluoroborane, closo-Borane, and closo-Carborane Salt Products (6-15 and 18).}

In order to minimize the presence of residual potassium halide by-product salt, the following general procedure was used for the large scale synthesis runs. An initial aqueous precipitation of the desired product occurred at $78-80{ }^{\circ} \mathrm{C}$, followed by slow cooling to $\mathrm{rt}$, placement in a refrigerator overnight, and isolation of the salt product by filtration. A subsequent aqueous digestion of the isolated precipitated solid product salt was conducted at $78-80{ }^{\circ} \mathrm{C}$, followed by slow cooling, and placement in a refrigerator overnight. Filtration, and final drying in an Electrothermal Chem-Dry ${ }^{\circledR}$ vacuum drying apparatus afforded solid salt products 6-15 and $\mathbf{1 8 .}$

A $100 \mathrm{~mL}$ beaker, containing with a one-half inch Teflon-Coated magnetic stirring bar, was charged with the selected bridged heterocyclium di-cation di-halide salt (1-5) which was dissolved at $\mathrm{rt}$ in de-ionized (DI) water. A second $100 \mathrm{~mL}$ beaker was charged with a nearly stoichiometric amount of potassium closo-perfluoroborane, closo-borane, or closocarborane which was then dissolved at rt in DI water. Both beakers were then placed for 15 min on a hot plate/stirrer that was calibrated to hold $25 \mathrm{~mL}$ DI water at 78 to $80{ }^{\circ} \mathrm{C}$ after a 15 min warming time. The beaker with the di-halide reactant salt was stirred while the beaker with the potassium closo-borane-based salt was occasionally swirled. Constant volume in both beakers was maintained by use of glass covers and/or by adding DI water as needed. The aqueous potassium borane-based solution was then added dropwise to the stirred aq dihalide reactant salt solution over several minutes duration using a disposable capillary pipette. Immediately or nearly so, precipitation was noted. The spent potassium closoborane-based beaker was rinsed with $2 \times 1 \mathrm{~mL}$ DI water, and each rinse was added to the stirred aqueous suspension in the beaker containing the reaction suspension (Total addition time was from 5 to $17 \mathrm{~min}$, including addition of the DI water rinses, is noted for each product salt). The beaker containing the suspension was covered and allowed to cool to rt before being covered with Parafilm ${ }^{\mathrm{TM}}$ and placed in the refrigerator $\left(+3.0^{\circ} \mathrm{C}\right)$ at least overnight. The cold suspension was suction filtered to give a solid cake of the desired product salt, the beaker was rinsed with $2 \times 1 \mathrm{~mL}$ pre-chilled $\left(+3.0^{\circ} \mathrm{C}\right) \mathrm{DI}$ water and each rinse was passed through the solid cake which was air dried of excess water under suction. The semi-dried solid cake was placed back into the same $50 \mathrm{~mL}$ beaker with the same stirring bar, and a defined amount of fresh DI water was added to affect a suspension. The stirred suspension was digested on the same hot plate/stirrer in the glass covered $50 \mathrm{~mL}$ beaker for $30 \mathrm{~min}$ at $78-80{ }^{\circ} \mathrm{C}$ to remove any residual potassium halide. The beaker and its contents were cooled to rt; the beaker was covered with Parafilm ${ }^{\mathrm{TM}}$, and then, was placed into the refrigerator $\left(3.0^{\circ} \mathrm{C}\right)$ at least overnight. Cold vacuum filtration, rinsing the beaker with $2 \times 1 \mathrm{~mL}$ pre-chilled DI water, and air drying a defined time gave a semi-dry solid 
which was transferred to a tarred 4 dram bottle that was subjected to high vacuum drying at $65{ }^{\circ} \mathrm{C}\left(50{ }^{\circ} \mathrm{C}\right.$ for product salt 9 to give the final bridged heterocyclium di-cation closoperfluoroborane, borane, or carborane salt product.

[1,4-di-(4-amino-1,2,4-triazolium-1N)-2-butyne][closo- $\left.\mathbf{B}_{\mathbf{1 2}} \mathbf{H}_{\mathbf{1 2}}\right]$ (6): Reacting 1.550 $\mathrm{g}(4.078 \mathrm{mmol})$ of 1,4-di-(4-amino-1,2,4-triazolium-1N)-2-butyne di-bromide (1) in $8 \mathrm{~mL}$ DI water with $0.879 \mathrm{~g}(3.996 \mathrm{mmol})$ of $\mathrm{K}_{2}\left[\mathrm{~B}_{12} \mathrm{H}_{12}\right]$ in $12 \mathrm{~mL}$ DI water, added over $8 \mathrm{~min}$, gave a solid product salt. Digestion of the solid product salt with $7 \mathrm{~mL}$ fresh DI water, when dried under high vacuum at $65^{\circ} \mathrm{C}$ for $71 \mathrm{~h}$, gave $1.347 \mathrm{~g}$ of a slightly off-white solid product salt 6 (93.1\% yield): ${ }^{1} \mathrm{H}$ NMR $400 \mathrm{MHz}$, std. DMSO-d 6 ( $\left.\delta 2.50\right) ; \delta 10.23(\mathrm{~s}, 2 \mathrm{H}), 9.27$ (s, $2 \mathrm{H}),(7.00$ (brs, $4 \mathrm{H}), 5.50$ (s, 4H), 1.30-0.38 (very brm, $12 \mathrm{H}) ;{ }^{13} \mathrm{C}$ NMR $(100 \mathrm{MHz}$, std. DMSO-d $_{6}(\delta 39.51) ; \delta 145.69,143.01,78.88,41.92$; FTIR (HATR) cm ${ }^{-1}, 3336,3269,3118$, 3054, 2969, 2936, 2524 (B-H), 2449 (B-H), 1602, 1556, 1523, 1414, 1350, 1272, 1198, $1160,1061,1014,944,895,772,706,635,607$; HRMS calcd for $\left[\right.$ Cation $^{2+}+2$ Anion $^{2-}+$ $\left.\mathrm{Na}^{+}\right]^{-}$527.5345, found 527.5351.

[1,4-di-(4-amino-1,2,4-triazolium-1N)-2-butyne][closo-CB $\left.\mathbf{C B}_{11} \mathbf{H}_{12}\right]$ (7): Reacting 1.450 $\mathrm{g}(3.815 \mathrm{mmol})$ of 1,4-di-(4-amino-1,2,4-triazolium-1N)-2-butyne di-bromide (1) in $7 \mathrm{~mL}$ DI water with $1.362 \mathrm{~g}(7.477 \mathrm{mmol})$ of $\mathrm{K}\left[\mathrm{CB}_{11} \mathrm{H}_{12}\right]$ in $7 \mathrm{~mL}$ DI water, added over $6 \mathrm{~min}$, gave a solid product salt. [Note: Care must be taken to ensure thorough mixing is acheived with this reaction.] Digestion of the solid product salt with $7 \mathrm{~mL}$ fresh DI water, when dried under high vacuum at $65{ }^{\circ} \mathrm{C}$ for $71 \mathrm{~h}$, gave $1.736 \mathrm{~g}$ of a light brown solid product salt $7(91.7$ \% yield): ${ }^{1} \mathrm{H}$ NMR $400 \mathrm{MHz}$, std. DMSO-d 6 ( $\left.\delta 2.50\right) ; \delta 10.24(\mathrm{~s}, 2 \mathrm{H}), 9.27(\mathrm{~s}, 2 \mathrm{H}),(7.01$ (brs, 4H), 5.49 (s, 4H), 2.38 (brs, 2H), 2.11-0.90 (very brm, 22H); ${ }^{13} \mathrm{C}$ NMR (100 MHz, std. DMSO-d $_{6}(\delta 39.51) ; \delta 145.68,143.02,78.87,50.71,41.90 ;$ FTIR (HATR) cm ${ }^{-1}, 3352,3278$, 3239, 3135, 3093, 2980, 2946, 2559 (B-H), 2520 (B-H), 1626, 1426, 1414, 1354, 1171, 1141, 1090, 1023, 999, 931, 894, 860, 840, 758, 717, 687, 638, 609; HRMS calcd for [Cation $^{2+}+$ Anion $\left.^{-}\right]^{+}$363.3215, found 363.3214.

[trans-1,4-di-(4-amino-1,2,4,-triazolium-1N)-2-butene][closo- $\left.\mathrm{B}_{12} \mathrm{H}_{12}\right](8)$ : Reacting $1.438 \mathrm{~g}$ (3.763 mmol) of trans-1,4-di-(4-amino-1,2,4-triazolium-1N)-2-butene di-bromide (2) in $9 \mathrm{~mL}$ DI water with $0.827 \mathrm{~g}(3.759 \mathrm{mmol})$ of $\mathrm{K}_{2}\left[\mathrm{~B}_{12} \mathrm{H}_{12}\right]$ in $12 \mathrm{~mL}$ DI water, added over $10 \mathrm{~min}$, gave a solid product salt. Digestion of the solid product salt with $10 \mathrm{~mL}$ fresh DI water, when dried under high vacuum at $50{ }^{\circ} \mathrm{C}$ for $90 \mathrm{~h}$, gave $1.272 \mathrm{~g}$ of a white solid product salt 8 (92.9 \% yield): ${ }^{1} \mathrm{H}$ NMR $400 \mathrm{MHz}$, std. DMSO-d 6 ( $\left.\delta 2.50\right) ; \delta 10.13(\mathrm{~s}, 2 \mathrm{H})$, $9.22(\mathrm{~s}, 2 \mathrm{H}),(6.96(\mathrm{brs}, 4 \mathrm{H}), 6.06-6.05(\mathrm{~m}, 2 \mathrm{H}), 5.07-5.06(\mathrm{~m}, 4 \mathrm{H}), 1.32-0.38$ (very brm, $12 \mathrm{H}) ;{ }^{13} \mathrm{C}$ NMR $(100 \mathrm{MHz}$, std. DMSO-d 6 ( $\delta 39.51) ; \delta 145.45,142.88,128.28,52.52$; FTIR (HATR) $\mathrm{cm}^{-1}, 3332,3266,3120,3051,2967,2517$ (B-H), 2464 (B-H), 2444 (B-H), 1604, 1556, 1521, 1422, 1360, 1187, 1157, 1060, 1017, 982, 957, 894, 770, 707, 612; HRMS calcd for $\left[\text { Cation }^{2+}+2 \text { Anion }^{2-}+\mathrm{Na}^{+}\right]^{-} 529.5501$, found 529.5484 .

[trans-1,4-di-(4-amino-1,2,4,-triazolium-1N)-2-butene][closo-CB $\mathrm{CB}_{11} \mathrm{H}_{12}$ (9): Reacting $1.031 \mathrm{~g}(2.698 \mathrm{mmol})$ of trans-1,4-di-(4-amino-1,2,4-triazolium-1N)-2-butene dibromide (2) in $7 \mathrm{~mL}$ DI water with $0.982 \mathrm{~g}(5.391 \mathrm{mmol})$ of $\mathrm{K}\left[\mathrm{CB}_{11} \mathrm{H}_{12}\right]$ in $6 \mathrm{~mL}$ DI water, added over $7 \mathrm{~min}$, gave a solid product salt. Digestion of the solid product salt with $7 \mathrm{~mL}$ fresh DI water, when dried under high vacuum for $75 \mathrm{~h}$ at $50{ }^{\circ} \mathrm{C}$, gave $1.262 \mathrm{~g}$ of a white solid product salt 9 (92.1\% yield): ${ }^{1} \mathrm{H}$ NMR $400 \mathrm{MHz}$, std. DMSO-d 6 ( $\left.\delta 2.50\right) ; \delta 10.14$ (s, 
2H), 9.22 (s, 2H), (6.98 (brs, 4H), 6.06-6.05 (m, 2H), 5.06-5.05 (m, 4H), 2.38 (brs, 2H), 2.11-0.90 (very brm, 22H); ${ }^{13} \mathrm{C}$ NMR (100 MHz, std. DMSO-d 6 ( $\left.\delta 39.51\right) ; \delta 145.41,142.84$, 128.31, 52.50, 50.76; FTIR (HATR) $\mathrm{cm}^{-1}$, 3346, 3282, 3240, 3131, 3089, 2547(B-H), 2510 (B-H), 1707, 1625, 1558, 1434, 1361, 1312, 1150, 1149, 1088, 1066, 1022, 979, 922, 864, 765, 714, 608; HRMS calcd for [Cation ${ }^{2+}+$ Anion $]^{+} 365.3371$, found 365.3382.

[trans-1,4-di-(1-amino-1,2,3,-triazolium-3N)-2-butene][closo- $\mathrm{B}_{12} \mathrm{H}_{12}$ ] (10): Reacting $1.329 \mathrm{~g}(3.478 \mathrm{mmol})$ of trans-1,4-di-(1-amino-1,2,3-triazolium-3N)-2-butene di-bromide (3) in $7 \mathrm{~mL}$ DI water with $0.765 \mathrm{~g}(3.478 \mathrm{mmol})$ of $\mathrm{K}_{2}\left[\mathrm{~B}_{12} \mathrm{H}_{12}\right]$ in $8 \mathrm{~mL}$ DI water, added over $9 \mathrm{~min}$, gave a solid product salt. Digestion of the solid product salt with $6 \mathrm{~mL}$ fresh DI water, when dried for $96 \mathrm{~h}$ at $65{ }^{\circ} \mathrm{C}$ under high vacuum to give $1.192 \mathrm{~g}$ of a white solid product salt 10 (94.1 \% yield): ${ }^{1} \mathrm{H}$ NMR $400 \mathrm{MHz}$, std. DMSO-d ${ }_{6}(\delta 2.50) ; \delta 8.80-8.79(\mathrm{~d}$, $2 \mathrm{H}), 8.66(\mathrm{~d}, 2 \mathrm{H}), 8.37$ (brs, $4 \mathrm{H}), 6.17-6.16(\mathrm{~m}, 2 \mathrm{H}), 5.29-5.28(\mathrm{~m}, 4 \mathrm{H}), 1.30-0.38$ (very brm, $12 \mathrm{H}) ;{ }^{13} \mathrm{C}$ NMR $(100 \mathrm{MHz}$, std. DMSO-d 6 ( $\delta 39.51) ; \delta 130.93,128.57,126.83,53.42$; FTIR (HATR) cm $\mathrm{cm}^{-1}, 3324,3255,3174,3128,3041,2980,2942,2475$ (B-H), 2455 (B-H), 2438 (B-H), 1599, 1523, 1473, 1411, 1341, 1248, 1210, 1187, 1088, 1060, 971, 926, 791, 753, 708, 652, 620; HRMS calcd for $\left[\text { Cation }^{2+}+2 \mathrm{Anion}^{2-}+\mathrm{Na}^{+}\right]^{-} 528.5538$ found 528.5549 .

[trans-1,4-di-(1-amino-1,2,3,-triazolium-3N)-2-butene][closo-CB $\left.\mathrm{CB}_{11} \mathrm{H}_{12}\right]$ (11): Reacting $1.356 \mathrm{~g}$ (3.549 mmol) of trans-1,4-di-(1-amino-1,2,3-triazolium-3N)-2-butene dibromide (3) in $7 \mathrm{~mL}$ DI water with $1.293 \mathrm{~g}(7.100 \mathrm{mmol})$ of $\mathrm{K}\left[\mathrm{CB}_{11} \mathrm{H}_{12}\right]$ in $7 \mathrm{~mL}$ DI water, added over $8 \mathrm{~min}$, gave a solid product salt. Digestion of the solid product salt with $7 \mathrm{~mL}$ fresh DI water, when dried for $96 \mathrm{~h}$ at $65^{\circ} \mathrm{C}$ under high vacuum to give $1.760 \mathrm{~g}$ of a creamcolored solid product salt $11\left(97.5 \%\right.$ yield): ${ }^{1} \mathrm{H}$ NMR $400 \mathrm{MHz}$, std. DMSO-d $6(\delta 2.50) ; \delta$ $8.80(\mathrm{~d}, 2 \mathrm{H}), 8.66-8.65$ (d, 2H), 8.38 (brs, 4H), 6.16-6.15 (m, 2H), 5.28-5.27 (m, 4H), 2.39 (brs, 2H), 2.11-0.90 (very brm, 22H); ${ }^{13} \mathrm{C}$ NMR (100 MHz, std. DMSO-d 6 ( $\left.\delta 39.51\right) ; \delta$ 130.94, 128.57, 126.79, 53.41, 50.71; FTIR (HATR) $\mathrm{cm}^{-1}, 3338,3266,3146,3132,3090$, 2998, 2529 (B-H), 1523, 1196, 1167, 1087, 1022, 968, 901, 786, 759, 717, 651; HRMS calcd for $\left[\text { Cation }^{2+}+\text { Anion }^{-}\right]^{+} 365.3371$, found 365.3374 .

[cis-1,4-di-(4-amino-1,2,4,-triazolium-1N)-2-butene][closo- $\left.\mathbf{B}_{12} \mathrm{H}_{12}\right]$ (12): Reacting $1.256 \mathrm{~g}$ (4.286 mmol) of cis-1,4-di-(4-amino-1,2,4-triazolium-1N)-2-butene di-chloride (4) in $3 \mathrm{~mL}$ DI water with $0.848 \mathrm{~g}(3.856 \mathrm{mmol})$ of $\mathrm{K}_{2}\left[\mathrm{~B}_{12} \mathrm{H}_{12}\right]$ in $14 \mathrm{~mL}$ DI water, added over $17 \mathrm{~min}$, gave a solid product salt. Digestion of the solid product salt with $5 \mathrm{~mL}$ fresh DI water, when dried under high vacuum at $65^{\circ} \mathrm{C}$ for $96 \mathrm{~h}$, gave $1.299 \mathrm{~g}$ of a light brown solid product salt 12 (92.5\% yield): ${ }^{1} \mathrm{H}$ NMR $400 \mathrm{MHz}$, std. DMSO-d 6 ( $\left.\delta 2.50\right) ; \delta 10.15(\mathrm{~s}, 2 \mathrm{H})$, $9.22(\mathrm{~s}, 2 \mathrm{H}),(6.97$ (brs, 4H), 6.04-6.02 (m, 2H), 5.24-5.23 (m, 4H), 1.30-0.38 (very brm, $12 \mathrm{H}) ;{ }^{13} \mathrm{C}$ NMR $\left(100 \mathrm{MHz}\right.$, std. DMSO-d ${ }_{6}(\delta 39.51) ; \delta 145.36,142.80,127.38,48.62$; FTIR (HATR) $\mathrm{cm}^{-1}, 3337,3316,3306,3213,3123,3070,3003,2467$ (B-H), 2442 (B-H), 1613, 1564, 1532, 1436, 1406, 1323, 1164, 1057, 1006, 960, 950, 867, 806, 711, 651, 637, 605; HRMS calcd for $\left[\text { Cation }^{2+}+2 \mathrm{Anion}^{2-}+\mathrm{Na}^{+}\right]^{-} 529.5501$, found 529.5493 .

[cis-1,4-di-(4-amino-1,2,4,-triazolium-1N)-2-butene][closo-CB $\mathbf{C B}_{11} \mathrm{H}_{12}$ ] (13): Reacting $0.849 \mathrm{~g}$ (2.896 mmol) of cis-1,4-di-(4-amino-1,2,4-triazolium-1N)-2-butene di-chloride (4) in $4 \mathrm{~mL}$ DI water with $0.949 \mathrm{~g}(5.211 \mathrm{mmol})$ of $\mathrm{K}\left[\mathrm{CB}_{11} \mathrm{H}_{12}\right]$ in $6 \mathrm{~mL}$ DI water, added over 5 
min, gave a solid product salt. [Note: Initially, oil droplets formed, but as more potassium carborane solution was added, the brown oil solidified to a precipitate.] Digestion of the solid product salt with $7 \mathrm{~mL}$ fresh DI water, when dried under high vacuum at $65^{\circ} \mathrm{C}$ for 96 $\mathrm{h}$, gave $1.233 \mathrm{~g}$ of a light brown solid product salt 13 (93.1\% yield): ${ }^{1} \mathrm{H}$ NMR $400 \mathrm{MHz}$, std. DMSO-d 6 ( $\delta 2.50) ; \delta 10.16(\mathrm{~s}, 2 \mathrm{H}), 9.23(\mathrm{~s}, 2 \mathrm{H}),(6.99(\mathrm{brs}, 4 \mathrm{H}), 6.04-6.02(\mathrm{~m}, 2 \mathrm{H})$, 5.23-5.22 (m, 4H), 2.38 (brs, 2H), 2.11-0.90 (very brm, 22H); ${ }^{13} \mathrm{C}$ NMR (1 $00 \mathrm{MHz}$, std. DMSO-d $_{6}(\delta 39.51) ; \delta 145.33,142.79,127.41,50.71,48.56$; FTIR (HATR) cm ${ }^{-1}, 3355$, 3288, 3248, 3135, 3099, 2537 (B-H), 1637, 1466, 1443, 1403, 1325, 1149, 1088, 1021, 891, 836, 713, 649; 610 HRMS calcd for $\left[\text { Cation }^{2+}+\text { Anion }^{-}\right]^{+}$365.3371, found 365.3382.

[trans-1,4-di-(1-methylimidazolium-3N)-2-butene][closo- $\mathrm{B}_{12} \mathrm{H}_{12}$ ] (14): Reacting $1.437 \mathrm{~g}$ (3.802 mmol) of trans-1,4-di-(1-methylimidazolium-3N)-2-butene di-bromide (5) in $5 \mathrm{~mL}$ DI water with $0.823 \mathrm{~g}(3.762 \mathrm{mmol})$ of $\mathrm{K}_{2}\left[\mathrm{~B}_{12} \mathrm{H}_{12}\right]$ in $10 \mathrm{~mL}$ DI water, added over 9 min gave a solid product salt. Digestion of the solid product salt with $10 \mathrm{~mL}$ fresh DI water, when dried for $69.5 \mathrm{~h}$ at $65^{\circ} \mathrm{C}$ under high vacuum (45-50 mTorr) to gave $1.307 \mathrm{~g}$ of a white solid product salt 14 (96.4 \% yield): ${ }^{1} \mathrm{H}$ NMR $400 \mathrm{MHz}$, std. DMSO-d 6 ( $\left.\delta 2.50\right) ; \delta 9.07$ (s, 2H), 7.74-7.73 (m, 2H), 7.70-7.69 (m, 2H), 5.98-5.97 (m, 2H), 4.88-4.87 (m, 4H), 3.86 (s, $6 \mathrm{H}), 1.31-0.38$ (very brm, $12 \mathrm{H}) ;{ }^{13} \mathrm{C}$ NMR (100 MHz, std. DMSO-d 6 ( $\left.\delta 39.51\right) ; \delta 136.61$, 129.00, 123.84, 122.32, 49.44, 35.89; FTIR (HATR) $\mathrm{cm}^{-1}, 3146,3108,3030,2943,2828$, 2475 (B-H), 2452 (B-H), 2435 (B-H), 1723, 1678, 1618, 1574, 1557, 1452, 1368, 1333, 1295, 1266, $11901155,1066,974,838,752,720,656,620$; HRMS calcd for [Cation ${ }^{2+}+$ 2 Anion $\left.^{2-}+\mathrm{Na}^{+}\right]^{-} 525.5691$ found 525.5708 .

[trans-1,4-di-(1-methylimidazolium-3N)-2-butene][closo- $\mathrm{CB}_{11} \mathrm{H}_{12}$ ] (15): Reacting $1.029 \mathrm{~g}(2.720 \mathrm{mmol})$ of trans-1,4-di-(1-methylimidazolium-3N)-2-butene di-bromide (5) in $4 \mathrm{~mL}$ DI water with $0.990 \mathrm{~g}(5.438 \mathrm{mmol})$ of $\mathrm{K}\left[\mathrm{CB}_{11} \mathrm{H}_{12}\right]$ in $6 \mathrm{~mL}$ DI water, added over 10 min gave a solid product salt. Digestion of the solid product salt with $7 \mathrm{~mL}$ fresh DI water, when dried for $69.5 \mathrm{~h}$ at $65{ }^{\circ} \mathrm{C}$ under high vacuum (45-50 mTorr) to gave $1.332 \mathrm{~g}$ of a white solid product salt 15 (97.1\% yield): ${ }^{1} \mathrm{H}$ NMR $400 \mathrm{MHz}$, std. DMSO-d 6 ( $\left.\delta 2.50\right) ; \delta 9.08(\mathrm{~s}$, $2 \mathrm{H}), 7.74-7.73(\mathrm{~m}, 2 \mathrm{H}), 7.70-7.69(\mathrm{~m}, 4 \mathrm{H}), 5.97-5.96(\mathrm{~m}, 2 \mathrm{H}), 4.87-4.86(\mathrm{~m}, 4 \mathrm{H}), 3.86(\mathrm{~s}$, $6 \mathrm{H}$ ), 2.39 (brs, 2H), 2.08-0.90 (very brm, 22H); ${ }^{13} \mathrm{C}$ NMR (100 MHz, std. DMSO-d 6 ( $\delta$ 39.51); $\delta 136.63,129.01,123.85,122.31,49.43,35.86$; FTIR (HATR) cm ${ }^{-1}, 3281,3235$, 3162, 3147, 3102, 2537 (B-H), 1595, 1565, 1444, 1384, 1358, 1334, 1295, 1159, 1087 , 1021, 980, 890, 827, 739, 716, 617; HRMS calcd for $\left[\text { Cation }^{2+}+\text { Anion }^{-}\right]^{+} 361.3561$, found 361.3577 .

[trans-1,4-di-(4-amino-1,2,4-triazolium-1N)-2-butene][closo-B $\left.\mathbf{B}_{12} \mathbf{F}_{12}\right]$ (16): Reacting $0.773 \mathrm{~g}(2.024 \mathrm{mmol})$ of trans-1,4-di-(4-amino-1,2,4-triazolium-1N)-2-butene di-bromide (2) in $4 \mathrm{~mL}$ DI water with $0.865 \mathrm{~g}(1.984 \mathrm{mmol})$ of $\mathrm{K}_{2}\left[\mathrm{~B}_{12} \mathrm{~F}_{12}\right]$ in $6 \mathrm{~mL}$ DI water, added over $9 \mathrm{~min}$, gave a solid product salt. Digestion of the solid product salt with $6 \mathrm{~mL}$ fresh DI water, when dried for $72 \mathrm{~h}$ at $\mathrm{rt}$ under a high vacuum line to $18 \mathrm{mTorr}$, gave $1.058 \mathrm{~g}$ of a white solid product salt 16 (92.0\% yield): ${ }^{1} \mathrm{H}$ NMR $400 \mathrm{MHz}$, std. DMSO-d 6 ( $\left.\delta 2.50\right) ; \delta$ 10.14 (s, 2H), 9.22 (s, 2H), (6.97 (brs, 4H), 6.06-6.05 (m, 2H), 5.06-5.05 (m, 4H); ${ }^{13} \mathrm{C} \mathrm{NMR}$ $\left(100 \mathrm{MHz}\right.$, std. DMSO-d $6(\delta 39.51) ; \delta 145.40,142.83,128.30,52.94 ;$ FTIR $\left(\right.$ HATR $\mathrm{cm}^{-1}$, $3393,3321,3150,3107,3009,2975,1620,1560,1440,1371,1221\left[\mathrm{~B}_{12} \mathrm{~F}_{12}\right]^{2-}, 1149,1072$, $1003,971,935,875,723\left[\mathrm{~B}_{12} \mathrm{~F}_{12}\right]^{2-}, 640,612$; HRMS (from smaller scale sample shown 
below) calcd for [Cation $\left.{ }^{2+}-\mathrm{H}^{+}\right]^{+}$221.1263, found 221.1258 in positive mode, and HRMS calcd for $\left[\mathrm{Cation}^{2+}+\text { Anion }^{2-}-\mathrm{H}^{+}\right]^{-} 579.2266$, found 579.2284 in the negative mode.

[1,4-di-(4-amino-1,2,4-triazolium-1N)-2-butyne][closo- $\left.\mathbf{B}_{\mathbf{1 2}} \mathbf{F}_{\mathbf{1 2}}\right]$ (18): Reacting 0.821 $\mathrm{g}(2.159 \mathrm{mmol})$ of 1,4-di-(4-amino-1,2,4-triazolium-1N)-2-butyne di-bromide (1) in $4 \mathrm{~mL}$ DI water with $0.922 \mathrm{~g}(2.115 \mathrm{mmol})$ of $\mathrm{K}_{2}\left[\mathrm{~B}_{12} \mathrm{~F}_{12}\right]$ in $11 \mathrm{~mL} \mathrm{DI} \mathrm{water,} \mathrm{added} \mathrm{over} 9 \mathrm{~min}$, gave a solid product salt. Digestion of the solid product salt with $5 \mathrm{~mL}$ fresh DI water, when dried for $38 \mathrm{~h}$ at rt on a high vacuum to $12 \mathrm{mTorr}$, gave $1.084 \mathrm{~g}$ of a cream-colored solid product salt 18 (88.7 \% yield): ${ }^{1} \mathrm{H}$ NMR $400 \mathrm{MHz}$, std. DMSO-d 6 ( $\left.\delta 2.50\right) ; \delta 10.24(\mathrm{~s}, 2 \mathrm{H})$, 9.26 (s, 2H), (7.01 (brs, 4H), 5.49 (s, 4H); ${ }^{13} \mathrm{C}$ NMR (100 MHz, std. DMSO-d 6 ( $\left.\delta 39.51\right) ; \delta$ 145.65, 142.99, 78.84, 41.88; FTIR (HATR) $\mathrm{cm}^{-1}$, 3372, 3309, 3149, 3107, 3013, 2985, $2966,1630,1568,1429,1361,1219\left[\mathrm{~B}_{12} \mathrm{~F}_{12}\right]^{2-}, 1074,1002,957,886,724\left[\mathrm{~B}_{12} \mathrm{~F}_{12}\right]^{2-}, 650$, 612; HRMS calcd for $\left[\text { Cation }^{2+}+\text { Anion }^{2-}-\mathrm{H}^{+}\right]^{-}$577.2110, found 577.2093.

Smaller-Scale General Metathesis Reaction Procedure and X-ray Data for Bridged Heterocyclium Di-Cation closo-Perfluoroborane Salt Products (16-18). Because of the limited supply of $\mathrm{K}_{2}\left[\mathrm{~B}_{12} \mathrm{~F}_{12}\right]$ and $\mathrm{Cs}_{2}\left[\mathrm{~B}_{12} \mathrm{~F}_{12}\right]$ reactant salts, the [Heterocyclium dication $]\left[\mathrm{B}_{12} \mathrm{~F}_{12}\right]$ salts initially were synthesized on a smaller reaction scale at $\mathrm{rt}$ with no digestion of the initial product salt. These three perfluoroborane salts are very soluble in $\mathrm{CH}_{3} \mathrm{CN}$ at rt; so, this solvent was used to obtain crystals suitable for single-crystal X-ray analyses shown below.

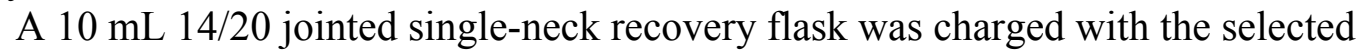
bridged heterocyclium di-cation di-halide salt $(\mathbf{2}, \mathbf{3}$, or $\mathbf{5})$ which was dissolved at $\mathrm{rt}$ in deionized (DI) water. A $50 \mathrm{~mL}$ beaker was charged with a nearly stoichiometric amount of potassium closo-perfluoroborane or cesium closo-perfluoroborane which was then dissolved at $\mathrm{rt}$ in DI water. The aqueous potassium or cesium perfluoroborane solution was added dropwise, using a disposable capillary pipette, to the aqueous solution in the $10 \mathrm{~mL}$ singlenecked recovery flask, and a precipitate immediately began to form. During addition, the flask occasionally was swirled. After complete addition, the beaker was rinsed with 0.4 to 1 $\mathrm{mL}$ DI water in two portions which was added to the $10 \mathrm{ml}$ recovery flask. The capped 10 $\mathrm{mL}$ recovery flask and its contents were placed overnight in a refrigerator $\left(+3.0^{\circ} \mathrm{C}\right)$. Vacuum filtration, rinsing the $10 \mathrm{~mL}$ recovery flask with 1 (salt 16), 2 (salt 17), or 3 (salt 18) $\mathrm{mL}$ of DI water, in two, two, and three portions, respectively, passing the rinses through the solid cake in the filtration funnel, and drying the resultant solid cake for at least $18 \mathrm{~h}$ at $75^{\circ} \mathrm{C}$ in a vacuum oven gave the desired product salt.

[trans-1,4-di-(4-amino-1,2,4-triazolium-1N)-2-butene][closo-B $\left.{ }_{12} \mathbf{F}_{12}\right]$ (16): Reacting $0.0443 \mathrm{~g}(0.1159 \mathrm{mmol})$ of 1,4-di-(4-amino-1,2,4-triazolium-1 $\mathrm{N})$-2-butene di-bromide (2) in $0.6 \mathrm{~mL}$ DI water with $0.0500 \mathrm{~g}(0.1147 \mathrm{mmol})$ of $\mathrm{K}_{2}\left[\mathrm{~B}_{12} \mathrm{~F}_{12}\right]$ in $0.6 \mathrm{~mL}$ DI water, added over less than one min, to give $0.0649 \mathrm{~g}(97.6 \%)$ of solid product salt 16: ${ }^{1} \mathrm{H}$ NMR $400 \mathrm{MHz}$, std. DMSO-d $_{6}(\delta 2.50) ; \delta 10.14(\mathrm{~s}, 2 \mathrm{H}), 9.22(\mathrm{~s}, 2 \mathrm{H}),(6.98(\mathrm{~s}, 4 \mathrm{H}), 6.06-6.05(\mathrm{~m}, 2 \mathrm{H}), 5.06-5.05$, $(\mathrm{m}, 4 \mathrm{H}) ;{ }^{13} \mathrm{C}$ NMR $(100 \mathrm{MHz}$, std. DMSO-d 6 ( $\delta 39.51) ; \delta 145.39,142.82,128.29,52.48$; FTIR (HATR) $\mathrm{cm}^{-1}, 3391,3322,3150,3097,3003,1622,1556,1438,1372,1221\left[\mathrm{~B}_{12} \mathrm{~F}_{12}\right]^{2-}$ , 1148, 1017, 1005, 972, 935, 874, $723\left[\mathrm{~B}_{12} \mathrm{~F}_{12}\right]^{2-}, 641,612$; HRMS calcd for [Cation ${ }^{2+}$ $\left.\mathrm{H}^{+}\right]^{+} 221.1263$, found 221.1258 in positive mode, and HRMS calcd for $\left[\mathrm{Cation}^{2+}+\mathrm{Anion}^{2-}\right.$ $\left.\mathrm{H}^{+}\right]^{-} 579.2266$, found 579.2284 in the negative mode. 
Recystallization from $\mathrm{CH}_{3} \mathrm{CN}$ to a very concentrated sample permitted single-crystal Xray analysis. Recrystallization from DI water also gave acceptable X-ray crystals: $23.3 \mathrm{mg}$ of salt 16 was dissolved in $20 \mathrm{~mL}$ boiling DI water. Filtration, cooling to rt, very slow air evaporation and concentration of the solution to $5 \mathrm{~mL}$, removal of excess water solvent with a disposable capillary pipette, and slow air drying of the resultant crystals gave $20.4 \mathrm{mg}$ of salt 16 for use in single-crystal X-ray analysis.

Table 1. Crystal and structure refinement data for $\mathbf{1 6 .}$

\begin{tabular}{|c|c|}
\hline & $(16)(4 \mathrm{AT})_{2} \mathrm{C}_{4} \mathrm{H}_{6} \mathrm{~B}_{12} \mathrm{~F}_{12}$ \\
\hline Formula & C8 H14 N8, B12 F12 \\
\hline Space group & $P 2_{1} / c$ monoclinic \\
\hline $\mathrm{a}(\AA)$ & $8.220(1)$ \\
\hline $\mathrm{b}(\AA)$ & $12.027(1)$ \\
\hline $\mathrm{c}(\AA)$ & $11.690(1)$ \\
\hline$\beta\left(\begin{array}{l}\circ \\
0\end{array}\right)_{2}$ & $105.839(1)$ \\
\hline$V / \AA^{3}$ & $1111.87(16)$ \\
\hline$\rho_{\text {calc }} / \mathrm{g} \mathrm{cm}^{-3}$ & 1.73 \\
\hline & 2 \\
\hline Formula weight & 579.99 \\
\hline$\mu / \mathrm{mm}^{-1}$ & 0.172 \\
\hline Temperature $(\mathrm{K})$ & $296(2)$ \\
\hline$\lambda(\operatorname{MoK} \alpha)$ & 0.71073 \\
\hline Crystal size & $0.1 \times 0.2 \times 0.2$ \\
\hline Theta range $\theta /{ }^{\circ}$ & 2.48 to 28.64 \\
\hline Index range & $-10 \leq \mathrm{h} \leq 10,-15 \leq \mathrm{k} \leq 15,-15 \leq \mathrm{l} \leq 15$ \\
\hline Reflection collected & 13074 \\
\hline Independent [R(int)]/ & $2700[0.0286]$ \\
\hline Obs. refl. ([I > $2.0 \sigma(\mathrm{I})])$ & 1823 \\
\hline $\mathrm{F}(000)$ & 572 \\
\hline GooF & 1.069 \\
\hline $\mathrm{R}_{1}, \mathrm{w} R[\mathrm{I}>2 \sigma(\mathrm{I})]$ & $0.0483,0.1388$ \\
\hline $\mathrm{R}_{1}, \mathrm{w} R_{2}($ all data $)$ & $0.0726,0.1559$ \\
\hline L.diff. peak/hole e $\AA^{3}$ & 0.28 and -0.21 \\
\hline Absorption correct. & multiscan SADABS \\
\hline $\mathrm{T}_{\min }, \mathrm{T}_{\max }$ & $0.662,0.746$ \\
\hline Data/restraints/param. & $2700 / 0 / 193$ \\
\hline Refinement method & Full-matrix least squares on $\mathrm{F}^{2}$ \\
\hline
\end{tabular}

CCDC-776032 contains the supplementary crystallographic data for this paper. These data can be obtained free of charge from the Cambridge Crystallographic Data Centre via http://www.ccdc.cam.ac.uk/ data_request/cif. 


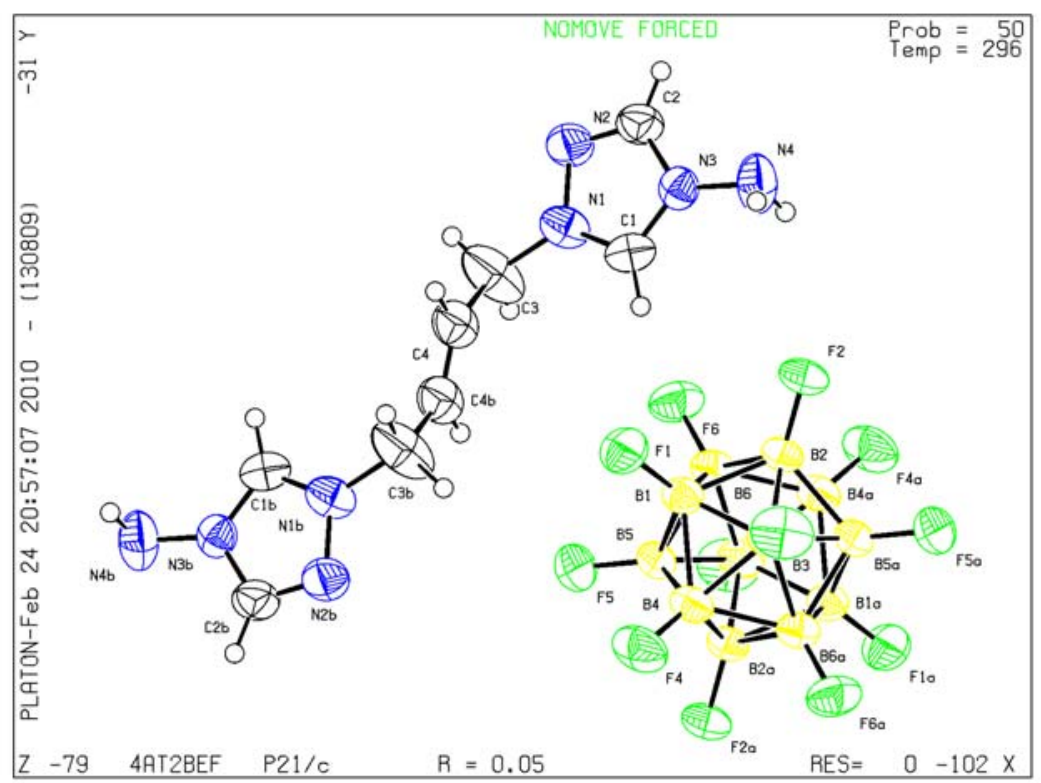

Figure 1. Molecular drawing of 16. Thermal ellipsoids are shown at 50\% probability level.

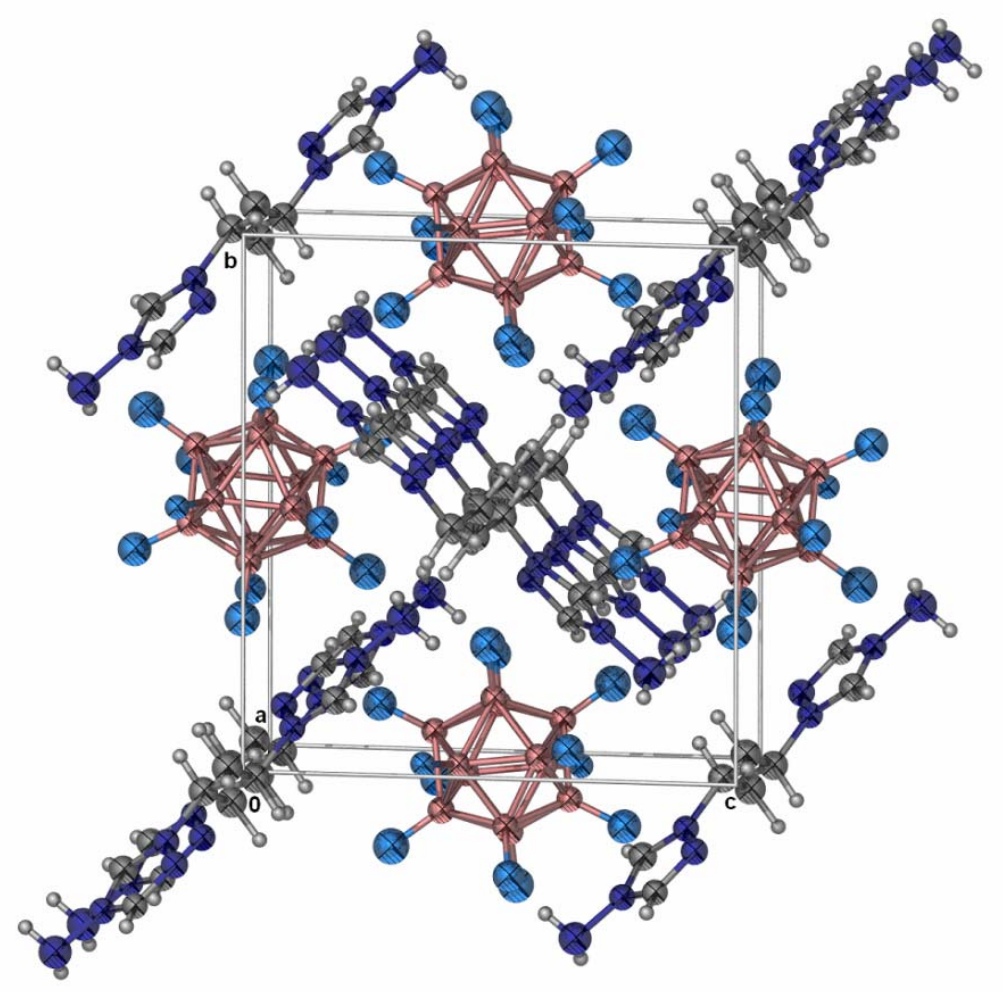

Figure 2. Crystal packing of $\mathbf{1 6}$ viewed along the $a$-axis (tiltel forward) 
[trans-1,4-di-(1-amino-1,2,3-triazolium-3N)-2-butene][closo-B $\left.{ }_{12} \mathbf{F}_{12}\right]$ (17): Reacting $0.0490 \mathrm{~g}(0.1282 \mathrm{mmol})$ of 1,4-di-(1-amino-1,2,3-triazolium-3N)-2-butene di-bromide (3) in $0.6 \mathrm{~mL}$ DI water with $0.0539 \mathrm{~g}(0.1236 \mathrm{mmol})$ of $\mathrm{K}_{2}\left[\mathrm{~B}_{12} \mathrm{~F}_{12}\right]$ in $0.6 \mathrm{~mL}$ DI water, added over less than one min, to give $0.0679 \mathrm{~g}(94.7 \%)$ of solid product salt 17: ${ }^{1} \mathrm{H}$ NMR $400 \mathrm{MHz}$, std. DMSO-d $_{6}(\delta 2.50) ; \delta 8.79(\mathrm{~d}, 2 \mathrm{H}), 8.65(\mathrm{~d}, 2 \mathrm{H}),(8.38$ (brs, 4H), 6.16-6.14 (m, 2H), 5.285.26, $(\mathrm{m}, 4 \mathrm{H}) ;{ }^{13} \mathrm{C}$ NMR $(100 \mathrm{MHz}$, std. DMSO-d 6 ( $\delta 39.51) ; \delta 130.91,128.56,126.79$, 53.40; FTIR (HATR) cm $\mathrm{cm}^{-1}, 3386,3311,3189,3174,1623,1530,1476,1414,1357,1330$, $1222\left[\mathrm{~B}_{12} \mathrm{~F}_{12}\right]^{2-}, 1087,980,904,790,726\left[\mathrm{~B}_{12} \mathrm{~F}_{12}\right]^{2-}, 659,628$; HRMS calcd for $\left[\right.$ Cation $^{2+}+$ Anion $\left.^{2-}-\mathrm{H}^{+}\right]^{-}$579.2266, found 579.2246.

Dissolving crude salt product 17 in $\mathrm{CH}_{3} \mathrm{CN}$ and evaporating to dryness gives crystals suitable for single-crystal X-ray analysis.

Table 2. Crystal and structure refinement data for 17.

\begin{tabular}{|c|c|}
\hline & $(17)(1 \mathrm{AT})_{2} \mathrm{C}_{4} \mathrm{H}_{4} \mathrm{~B}_{12} \mathrm{~F}_{12}$ \\
\hline Formula & $\mathrm{B} 12 \mathrm{~F} 12, \mathrm{C} 8 \mathrm{H} 14 \mathrm{~N} 8$ \\
\hline Space group & $P 2_{1} / n$ monoclinic \\
\hline $\mathrm{a}(\AA)$ & $8.318(1)$ \\
\hline $\mathrm{b}(\AA)$ & $13.311(1)$ \\
\hline$c(\AA)$ & $10.994(1)$ \\
\hline$\beta\left({ }^{\circ}\right)$ & $110.847(1)$ \\
\hline$V / \AA^{3}$ & $1137.55(5)$ \\
\hline$\rho_{\text {calc }} / \mathrm{g} \mathrm{cm}^{-3}$ & 1.69 \\
\hline & 2 \\
\hline Formula weight & 579.99 \\
\hline$\mu / \mathrm{mm}^{-1}$ & 0.168 \\
\hline Temperature $(\mathrm{K})$ & $296(2)$ \\
\hline$\lambda(\operatorname{MoK} \alpha)$ & 0.71073 \\
\hline Crystal size & $0.1 \times 0.1 \times 0.2$ \\
\hline Theta range $\theta /{ }^{\circ}$ & 2.50 to 25.46 \\
\hline Index range & $-10 \leq \mathrm{h} \leq 10,-16 \leq \mathrm{k} \leq 16,-13 \leq \mathrm{l} \leq 13$ \\
\hline Reflection collected & 21415 \\
\hline Independent $[\mathrm{R}($ int $)] /$ & $2099[0.0359]$ \\
\hline Obs. refl. $([\mathrm{I}>2.0 \sigma(\mathrm{I})])$ & 1600 \\
\hline $\mathrm{F}(000)$ & 572 \\
\hline GooF & 1.041 \\
\hline $\mathrm{R}_{1}, \mathrm{w} R[\mathrm{I}>2 \sigma(\mathrm{I})]$ & $0.0385,0.1023$ \\
\hline $\mathrm{R}_{1}, \mathrm{w}_{2}$ (all data) & $0.0539,0.1129$ \\
\hline L.diff. peak/hole e $\AA^{3}$ & 0.27 and -0.19 \\
\hline Absorption correct. & multiscan SADABS \\
\hline $\mathrm{T}_{\min }, \mathrm{T}_{\max }$ & $0.702,0.745$ \\
\hline Data/restraints/param. & $2099 / 398 / 289$ \\
\hline Refinement method & Full-matrix least squares on $\mathrm{F}^{2}$ \\
\hline
\end{tabular}

CCDC-776033 contains the supplementary crystallographic data for this paper. These data can be obtained free of charge from the Cambridge Crystallographic Data Centre via http://www.ccdc.cam.ac.uk/data_request/cif. 


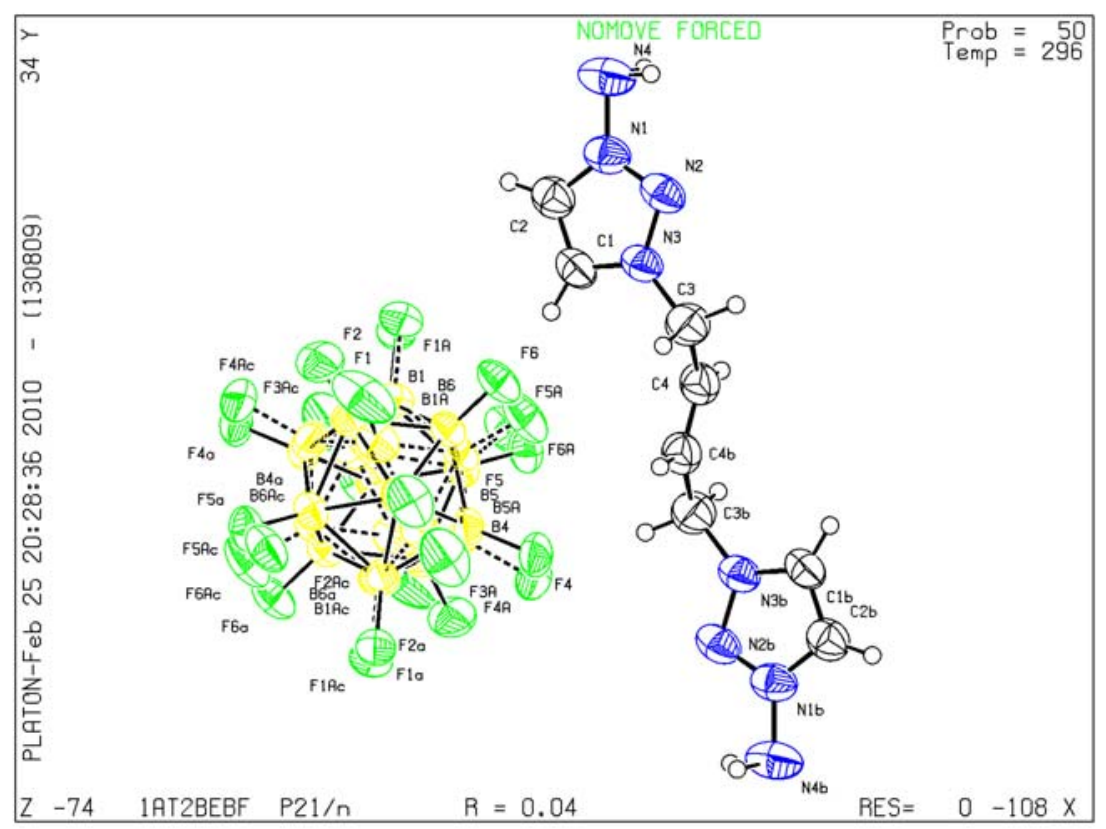

Figure 3. Molecular drawing of 17. Thermal ellipsoids are shown at 50\% probability level $\left(\mathrm{B}_{12} \mathrm{~F}_{12}{ }^{2-}\right.$ anion is disordered).

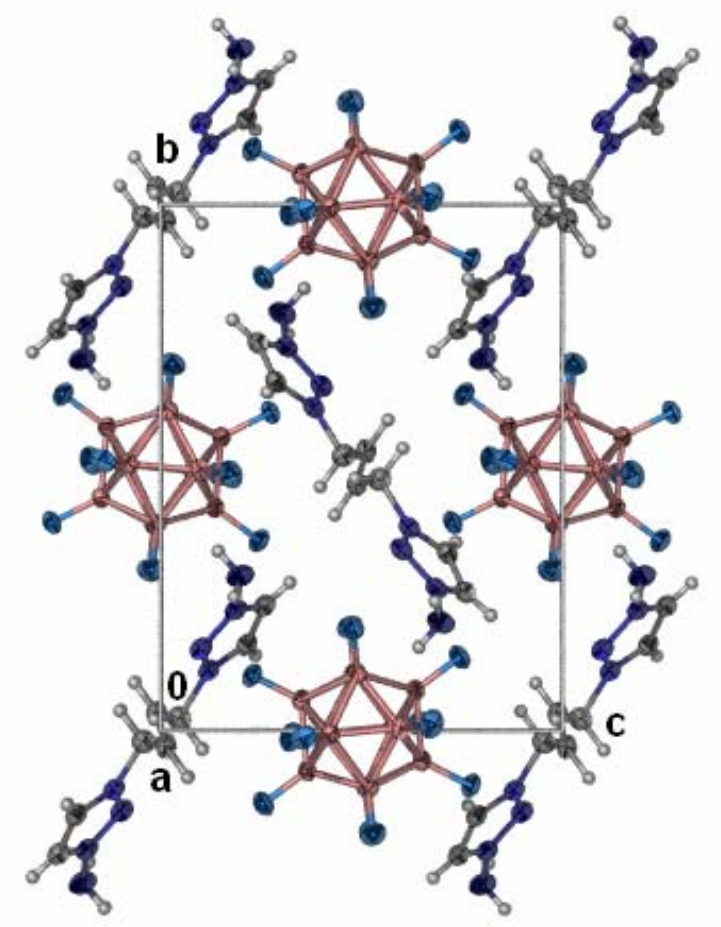

Figure 4. Crystal packing of 17 viewed along the $a$-axis (disorder removed for clarity). 
[1,4-di-(4-amino-1,2,4-triazolium-1N)-2-butyne][closo-B $\left.\mathbf{B}_{12} \mathrm{~F}_{12}\right]$ (18): Reacting $0.1084 \mathrm{~g}(0.2852 \mathrm{mmol})$ of 1,4-di-(4-amino-1,2,4-triazolium-1N)-2-butyne di-bromide (1) in $0.4 \mathrm{~mL}$ DI water with $0.1774 \mathrm{~g}(0.2845 \mathrm{mmol})$ of $\mathrm{Cs}_{2}\left[\mathrm{~B}_{12} \mathrm{~F}_{12}\right]$ in $5 \mathrm{~mL}$ (minimum amount needed) DI water, added over a couple of minutes, to give $0.1524 \mathrm{~g}(92.7 \%)$ of creamcolored solid product salt 18: ${ }^{1} \mathrm{H}$ NMR $400 \mathrm{MHz}$, std. DMSO-d 6 ( $\left.\delta 2.50\right) ; \delta 10.24(\mathrm{~s}, 2 \mathrm{H})$, $9.27(\mathrm{~s}, 2 \mathrm{H}),\left(7.01(\mathrm{~s}, 4 \mathrm{H}), 5.49,(\mathrm{~s}, 4 \mathrm{H}){ }^{13} \mathrm{C}\right.$ NMR $(100 \mathrm{MHz}$, std. DMSO-d 6 ( $\delta 39.51) ; \delta$ 145.66, 142.99, 78.85, 41.88; FTIR (HATR) $\mathrm{cm}^{-1}, 3375,3308,3151,3107,2985,2966$, $1631,1570,1430,1363,1218\left[\mathrm{~B}_{12} \mathrm{~F}_{12}\right]^{2-}, 959,887,725\left[\mathrm{~B}_{12} \mathrm{~F}_{12}\right]^{2-}, 716,652,613$; HRMS calcd for $\left[\text { Cation }^{2+}+\text { Anion }^{2-}-\mathrm{H}^{+}\right]^{-}$577.2110, found 577.2093.

Dissolving crude salt product 18 in $\mathrm{CH}_{3} \mathrm{CN}$ and evaporating to dryness gives crystals suitable for single-crystal X-ray analysis.

Table 3. Crystal and structure refinement data for $\mathbf{1 8}$

\begin{tabular}{|c|c|}
\hline & $(18)(1 \mathrm{AT})_{2} \mathrm{C}_{4} \mathrm{H}_{6} \mathrm{~B}_{12} \mathrm{~F}_{12}$ \\
\hline Formula & C8 H12 N8, B12 F12 \\
\hline Space group & Pbca orthorhombic \\
\hline $\mathrm{a}(\AA)$ & $17.066(1)$ \\
\hline $\mathrm{b}(\AA)$ & $14.648(1)$ \\
\hline c $(\AA)$ & $17.812(1)$ \\
\hline$\sigma, \beta, \gamma\left({ }^{\circ}\right)$ & 90 \\
\hline $\mathrm{V} / \AA^{3}$ & $4452.7(6)$ \\
\hline$\rho_{\text {calc }} / \mathrm{g} \mathrm{cm}^{-3}$ & 1.72 \\
\hline $\mathrm{Z}$ & 8 \\
\hline Formula weight & 577.98 \\
\hline$\mu / \mathrm{mm}^{-1}$ & 1.542 \\
\hline Temperature $(\mathrm{K})$ & $296(2)$ \\
\hline$\lambda(\mathrm{CuK} \alpha)$ & 1.54178 \\
\hline Crystal size & $0.1 \times 0.1 \times 0.2$ \\
\hline Theta range $\theta /{ }^{\circ}$ & 4.69 to 65.21 \\
\hline Index range & $-20 \leq \mathrm{h} \leq 16,-16 \leq \mathrm{k} \leq 14,-13 \leq \mathrm{l} \leq 20$ \\
\hline Reflection collected & 15709 \\
\hline Independent [R(int)]/ & $3670[0.0241]$ \\
\hline Obs. refl. $([\mathrm{I}>2.0 \sigma(\mathrm{I})])$ & 2768 \\
\hline $\mathrm{F}(000)$ & 2272 \\
\hline GooF & 1.048 \\
\hline $\mathrm{R}_{1}, \mathrm{w} R[\mathrm{I}>2 \sigma(\mathrm{I})]$ & $0.0468,0.1313$ \\
\hline $\mathrm{R}_{1}, \mathrm{w} R_{2}$ (all data) & $0.0630,0.1444$ \\
\hline L.diff. peak/hole e $\AA^{3}$ & 0.36 and -0.37 \\
\hline Absorption correct. & multiscan SADABS \\
\hline $\mathrm{T}_{\min }, \mathrm{T}_{\max }$ & $0.643,0.753$ \\
\hline Data/restraints/param. & $3670 / 0 / 377$ \\
\hline Refinement method & Full-matrix least squares on $\mathrm{F}^{2}$ \\
\hline
\end{tabular}

CCDC-776034 contains the supplementary crystallographic data for this paper. These data can be obtained free of charge from the Cambridge Crystallographic Data Centre via http://www.ccdc.cam.ac.uk/data_request/cif. 


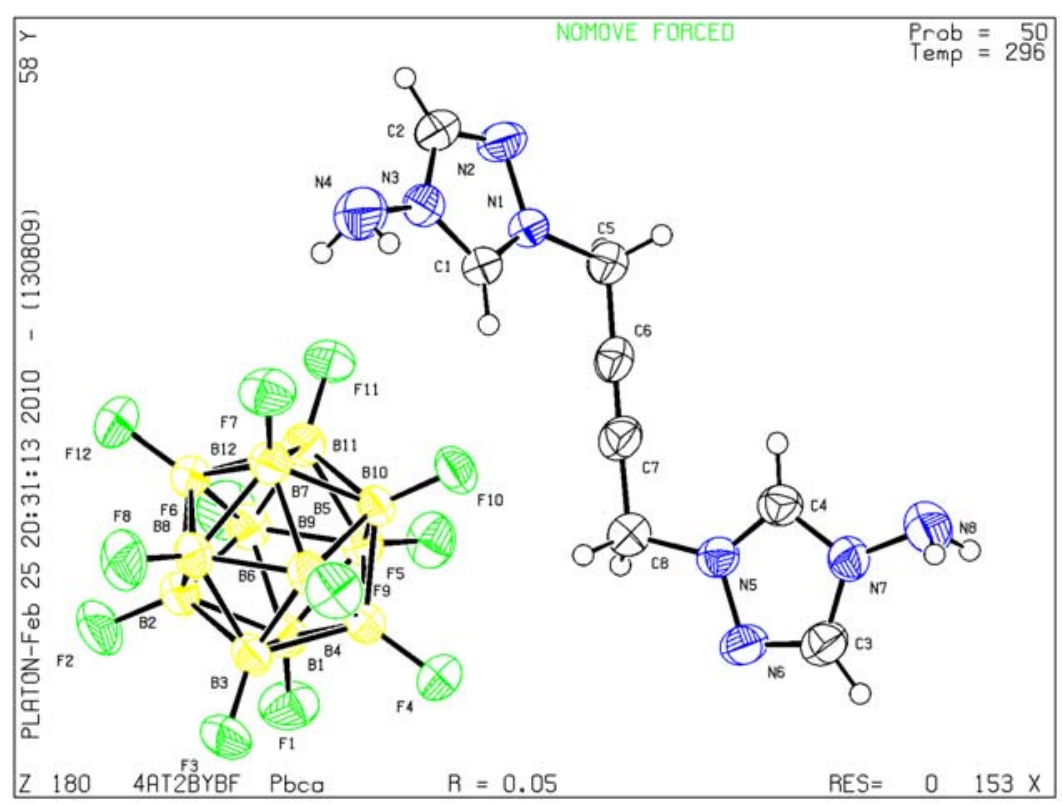

Figure 5. Molecular drawing of 18. Thermal ellipsoids are shown at 50\% probability level. 


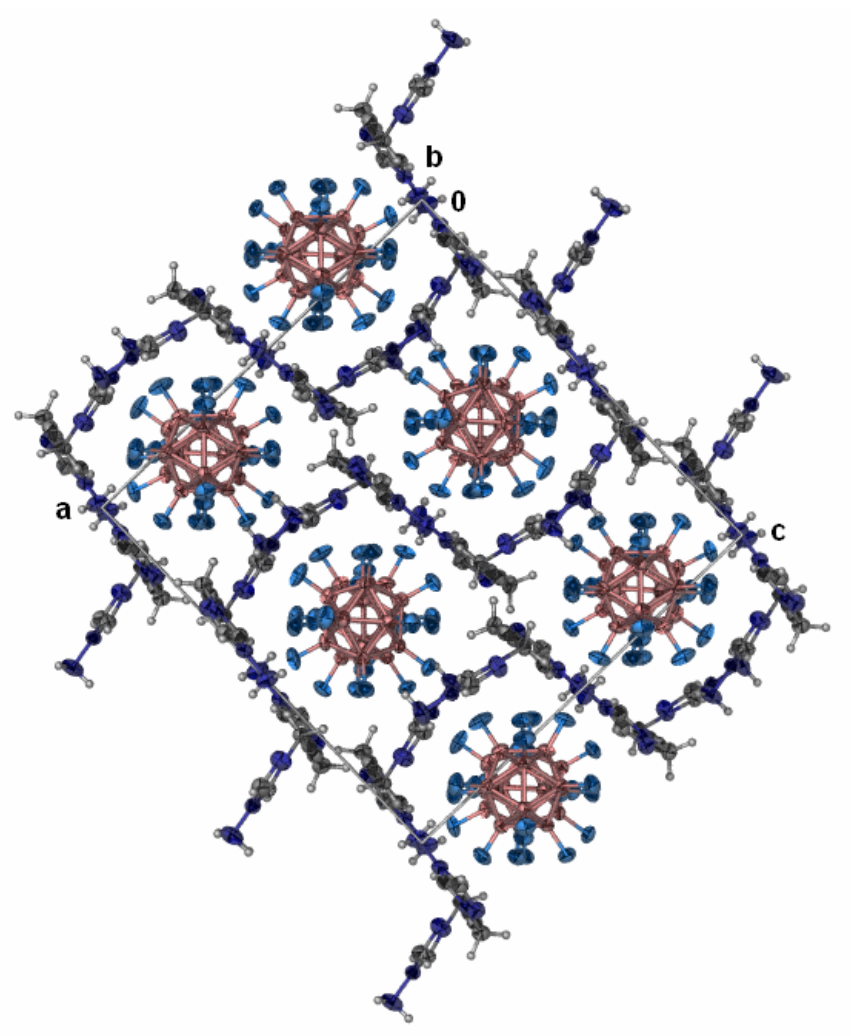

Figure 6. Crystal packing of $\mathbf{1 8}$ viewed along the $b$-axis.

\section{Melting Point Data.}

Detailed visual melting point behavior for all product salts (6-18) is presented in Supplemental Table 4. These values were determined as follows. First, a run was made at a $10{ }^{\circ} \mathrm{C} /$ minute temperature rise to obtain an approximate melting point value for each salt sample; then, a second run was made with each salt sample using a $1{ }^{\circ} \mathrm{C} /$ minute temperature rise beginning about $10{ }^{\circ} \mathrm{C}$ below the initial melt response.

This second run data was used to establish the published melting point or decomposition temperature values (Table 4) from iteratively comparing visual observations of each sample directly in the apparatus melting point compartment and the resultant video replay of that same sample. Softening means that the crystalline salt appeared to lose its sharp crystalline character to a more velvet-like solid that was devoid of sharp corners on the solid particles. 
Table 4. Melting Point Data Determined with the SRS MPA100 Apparatus.<smiles></smiles>

$\left[\mathrm{B}_{12} \mathrm{H}_{12}\right]^{2-}$

6<smiles></smiles>

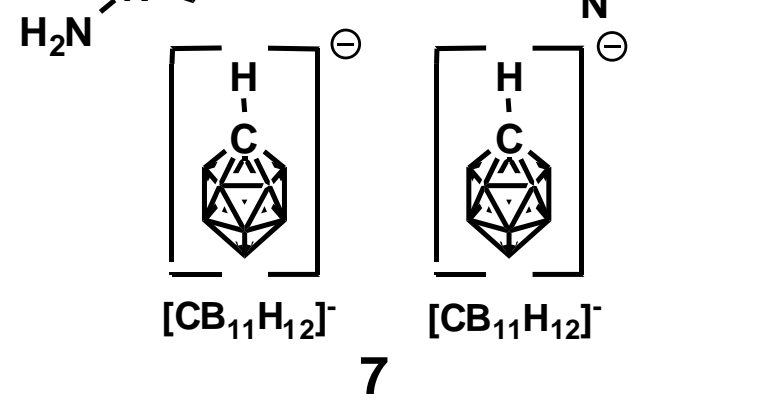

$\mathrm{H}_{2} \mathrm{~N}$ 、
DECOMPOSES with solid state gas evolution to a dark residue:

$$
217.4-219.6^{\circ} \mathrm{C}
$$

\section{LIQUIFIES to a brown oil} with decomposition:

175.5 - $178.5^{\circ} \mathrm{C}$

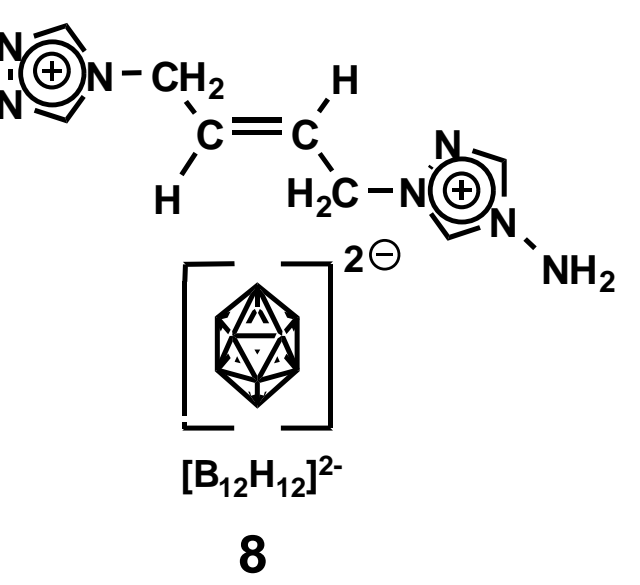

LIQUIFIES with rapid gas evolution:

238.7 - $239.6{ }^{\circ} \mathrm{C}$ 


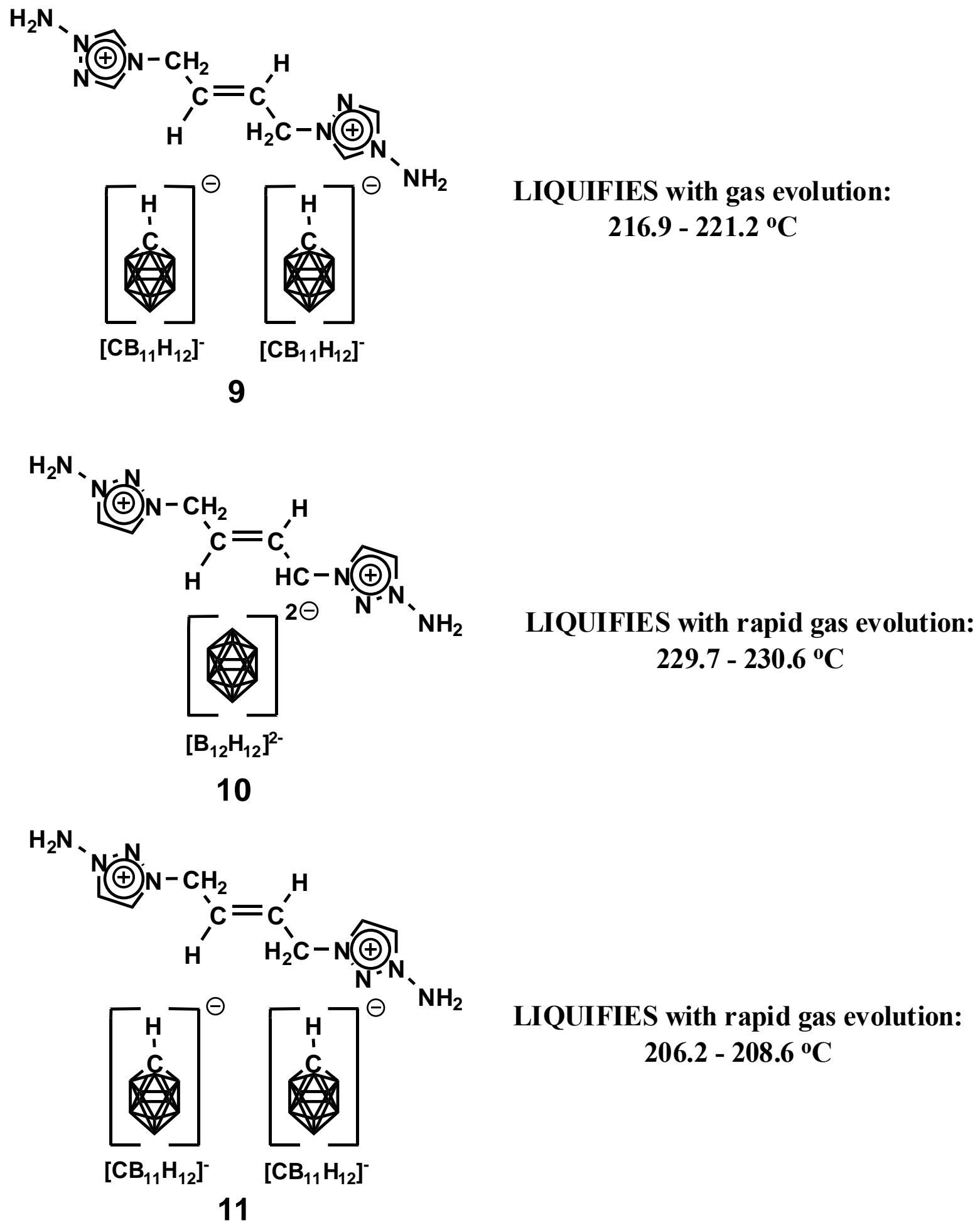




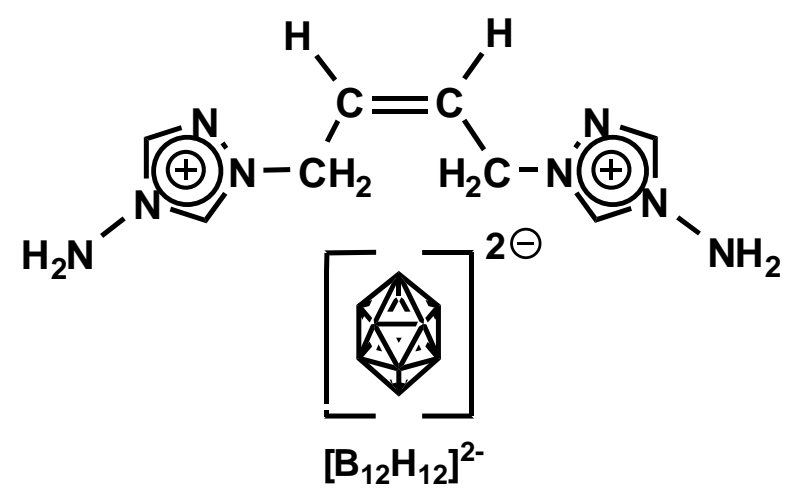

12

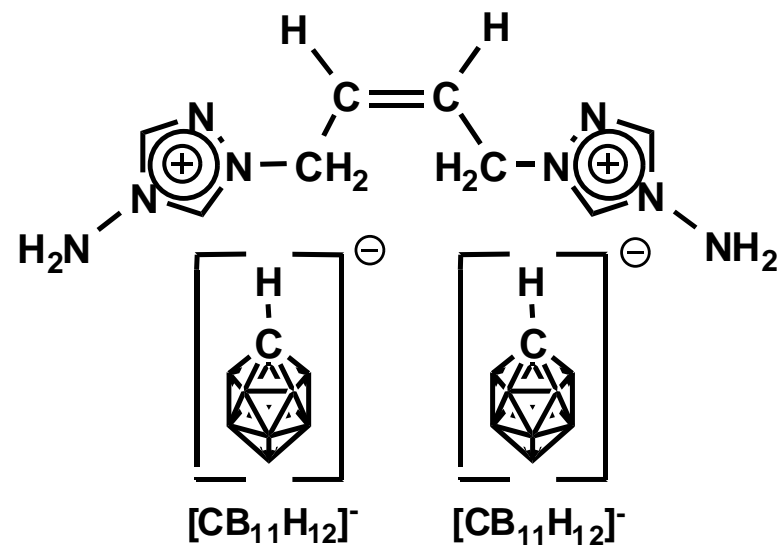

13
LIQUIFIES with gas evolution:

$238.9-240.0{ }^{\circ} \mathrm{C}$
LIQUIFIES slowly to a brown oil: 170.0 - $174.0^{\circ} \mathrm{C}$

$\mathrm{H}_{3} \mathrm{C}$ 、

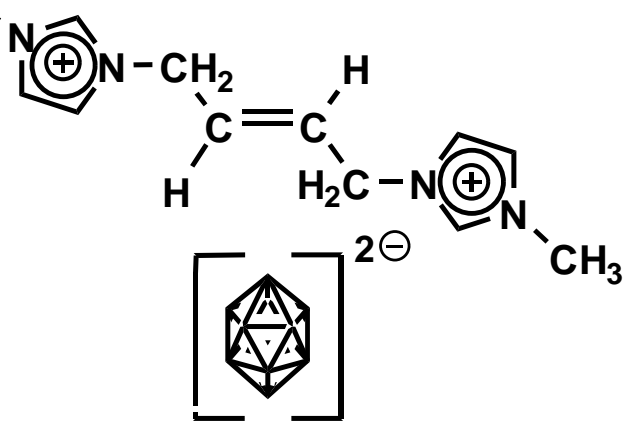

$\left[\mathrm{B}_{12} \mathrm{H}_{12}\right]^{2-}$
DECOMPOSITION in the solid state with very slow gas evolution to a brown residue: 305.1 - $398.0{ }^{\circ} \mathrm{C}$ 
$\mathrm{H}_{3} \mathrm{C}$ 、

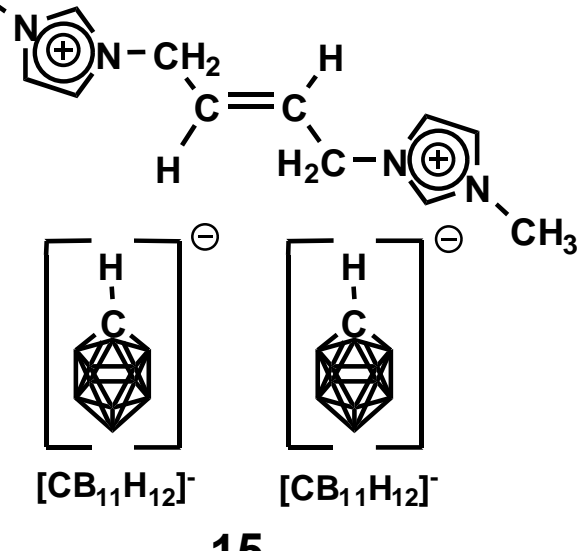

15

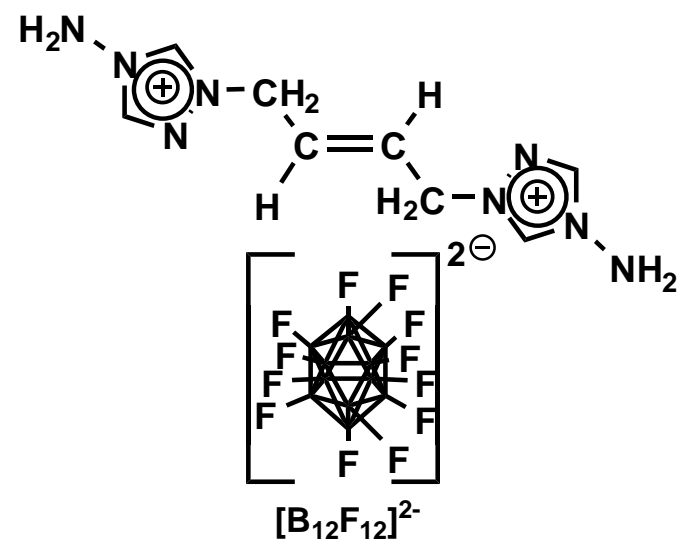

16 (Large Scale Digested Sample)

$\mathrm{H}_{2} \mathrm{~N}$,
SOFTENS with possible morphology change:

$210.1-231.4{ }^{\circ} \mathrm{C}$

LIQUIFIES with slight oil discoloration:

251.9 - $255.2{ }^{\circ} \mathrm{C}$
LIQUIFIES and darkens 302.8 - 303. ${ }^{\circ} \mathrm{C}$ with slow gas evolution noted at $303.6^{\circ} \mathrm{C}$

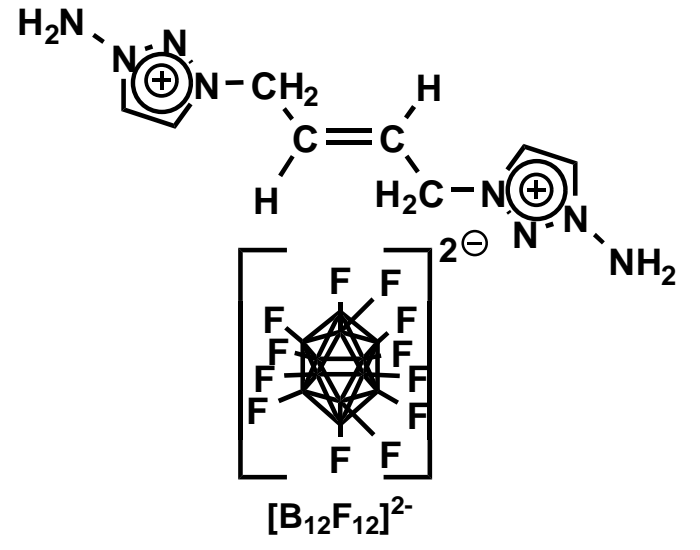

17 (Small Scale Sample)
LIQUIFIES and darkens with slow gas evolution:

$$
237.6 \text { - } 239.6{ }^{\circ} \mathrm{C}
$$




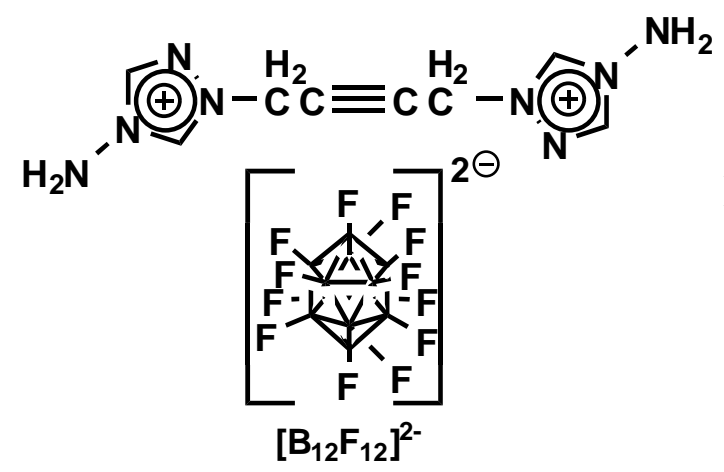

\section{LIQUIFIES and darkens to a dark brown oil with very slow gas evolution:} $236.5-238.5^{\circ} \mathrm{C}$

\section{8 (Large Scale Digested Sample)}

\section{Ion Chromatography $\mathrm{Cl}^{-}$or $\mathrm{Br}^{-}$Analysis Results.}

Ionic concentration was determined by Ion Chromatography using a Waters 1525 HPLC Binary Pump equipped with a Waters 432 conductivity detector and a Phenomenex ${ }^{\mathrm{TM}}$ STAR-IONTM A300 $100 \times 4.6$ mm ID (PEEK ${ }^{\mathrm{TM}}$ ) column. Each salt sample was weighed between $0.01 \mathrm{mg}$ to $00.08 \mathrm{mg}$, and in one case $0.03 \mathrm{mg}$, into a plastic class B centrifuge tube and diluted to $25 \mathrm{~mL}$ using Type 1 ultra pure water. Samples that did not readily dissolve were heated to $80^{\circ} \mathrm{C}$ with a plastic reflux cap. Each sample was passed through an IC Millex LG $0.2 \mu \mathrm{m}$ syringe filter prior to injection. A three point calibration curve was generated using blank reagent water, 1 and 10 ppm NIST traceable Chloride and Bromide standards. Concentrations were determined by comparing peak area response of the samples to the standard calibration curve. Run detection limits displayed for each salt vary depending upon the sample mass used in each analysis. As can be seen from Table 5 (page 24 ), the chloride ion content, from the residual $\mathrm{KCl}$ by-product, ranged from 0.3 to 0.5 weight percent, while the bromide content, from the residual $\mathrm{KBr}$ by-product $(\mathrm{CsBr}$ in the case of salt 18), ranged from less than 0.04 weight percent to 0.83 weight percent. 
Table 5. Ion Chromatography Residual $\mathrm{Cl}^{-}$or $\mathrm{Br}^{-}$Content in the Unsaturated Bridged Heterocyclium Di-Cation closo-Perfluoroborane, closo-Borane, and closo-Carborane Salts.

\begin{tabular}{|l|l|l|l|}
\hline Bridged Salt Product $^{\mathrm{a}}$ & $\begin{array}{l}\text { Run Detection Limit } \\
\text { (wt. \%) }\end{array}$ & $\underline{\mathbf{C l}^{-} \text {(wt. \%) }}$ & $\underline{\text { Br }^{-} \text {(wt. \%) }}$ \\
\hline $\mathbf{6}$ & 0.08 & --------- & $<0.08$ \\
\hline $\mathbf{7}$ & 0.08 & --------- & 0.10 \\
\hline $\mathbf{8}$ & 0.08 & --------- & 0.28 \\
\hline $\mathbf{9}$ & 0.08 & -------- & $<0.08$ \\
\hline $\mathbf{1 0}$ & 0.03 & 0.03 & -------- \\
\hline $\mathbf{1 1}$ & 0.03 & 0.05 & -------- \\
\hline $\mathbf{1 2}$ & 0.08 & --------- & $<0.08$ \\
\hline $\mathbf{1 3}$ & 0.07 & --------- & $<0.07$ \\
\hline $\mathbf{1 4}$ & 0.08 & --------- & 0.33 \\
\hline $\mathbf{1 5}$ & 0.08 & --------- & 0.83 \\
\hline $\mathbf{1 6}$ & 0.04 & --------- & $<0.04$ \\
\hline $\mathbf{1 7}$ (small scale) & 0.12 & --------- & $<0.12$ \\
\hline $\mathbf{1 8}$ & 0.08 & --------- & $<0.08$ \\
\hline $\mathbf{1 6}$ (small scale) & 0.10 & --------- & 0.50 \\
\hline $\mathbf{1 8}$ (small scale) & 0.08 & --------- & $<0.08$ \\
\hline
\end{tabular}

${ }^{\text {a }}$ All bridged heterocyclium dication product salts were synthesized using either the potassium borane, carborane, or perfluoroborane reactant salt except for the small scale salt 18 sample where a cesium perfluoroborane reactant was used. Water solubility of the $\mathrm{CsBr}$ by-product salt is more than two times greater than that of the $\mathrm{KBr}$ by-product salt. ${ }^{22}$ 